\title{
Dispute Resolution, ACCess to Civil Justice AND LEGAL EDUCATION
}

\author{
TrEYOR C.W. FARROW
}

This article examines current dispute resolution teaching and research programs in the comtext of improving access to justice through recent civil justice reform initiatives. Animated by exfensive domestic and international literature, online and survey-based research, the article explores the landscape of alternative dispute resolution education (primarily at law schools). comments on the need for continued thinking and reform and acts as a leading resource to assist in the ongoing, collaborative development of dispute resolution initiatives in legal education in Canada and abroad.
Cet article étudie l'enseignement ef les programmes de recherche courants porlant sur la résolution de confits dans te contexte d'amellorer l'acces à la justice au moyen des intialives récentes de réforme de la justice civile. Munie d'une imporiante documentation mationale ef internationale. de recherches à base de sondages et en direct. I'arficle explore l'enseignement de la résolution de conflits alternative (principalement, dans les écoles de droit). fait des commentaires sur le besoin de réflexion el de reforme continues, ef agif comme principale ressource dans le développement en participation continu des initiatives de résolution de conflits dans l'éducation juridique au Canada es d l'étranger.

\section{TABLE OF CONTENTS}

I. INTRODUCTION $\ldots \ldots \ldots \ldots \ldots \ldots \ldots \ldots \ldots \ldots \ldots \ldots \ldots \ldots \ldots \ldots \ldots$

II. DisPUTE RESOLUTION AND CIVIL JUSTICE

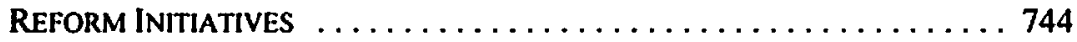

A. BACKGROUND ........................ 744

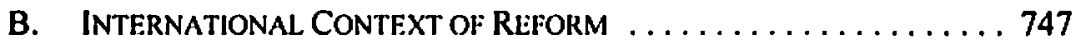

C. REForm IN CANAdA .................... 750

III. DiSPUTE RESOLUTION AND LEGAL EDUCATION . . . . . . . . . . . . 754

IV. Canadian Dispute Resolution Programs $\ldots \ldots \ldots \ldots \ldots \ldots \ldots 756$

A. BACKGROUND ...................... 756

B. UNIVERSITY INSTITUTES TOGETHER WITH

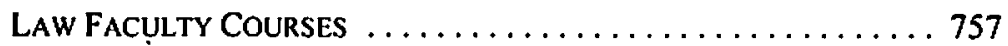

C. INTEgRATED - "PERVASIVE" - APPROACHES TO ADR . . . . . 760

D. "Traditional" Course-Based AdR Programs $\ldots \ldots \ldots \ldots \ldots 762$

E. UNIVERSITIES WITH OTHER LAW PROGRAMS . . . . . . . . . 768

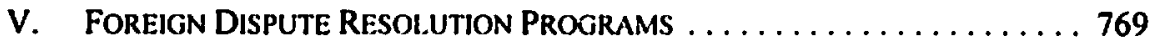

A. BACKGROUND ......................... 769

B. UnItEd States . . . . . . . . . . . . . . . . . . . 769

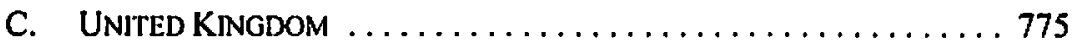

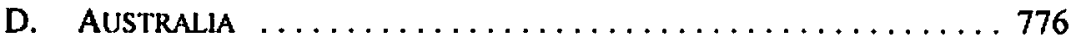

University of Alberta, Faculty of Law. This article has been influenced by a report that I prepared for the University of Alberta, Faculty of Law on the topic of teaching and researching dispute resolution. That report benefited from research support from the Jolan V. Decore Fund and the University of Alberta, Faculty of Law. I am grateful to Frank Sander. Fred Zemans, Collecn Hanyez and Michacla Keet for very helpful comments on an early draft of this article; to Diana J. Lowe. Executive Direclor of the Canadian Forum on Civil Justice (CFCJ) for helpful research suggestions and comments; to Michael Lines, Law Librarian and information Coordinator of the CFCJ, for research assistance; to lan Smith for extensive and excellent research assistance and comments; and finally, for helpful comments from the anonymous peer review process. 


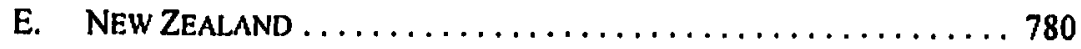

VI. Taking Stock: A "Great Beginning"

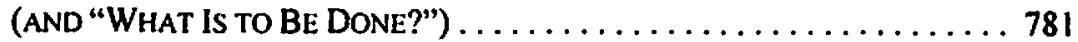

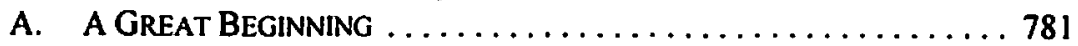

B. WHAT IS TO BE DONE? ..................... 782

C. POTENTIAL OBJECTIONS AND RESPONSES $\ldots \ldots \ldots \ldots \ldots \ldots \ldots, 796$

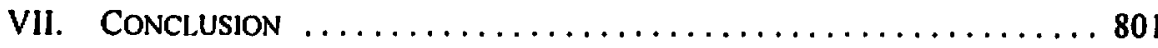

\section{INTRODUCTION}

ADR is an approach to justice whose time has come.'

In 1989, former Chief Justice of Canada Brian Dickson commented that "[i]t is an unfortunate fact that legal proceedings in the civil ... courts ... have become increasingly lengthy and protracted." $\mathrm{He}$ further argued, however, that notwithstanding this "unfortunate fact," courts "must ... remain accessible to the ordinary Canadian." The tension implicit in these observations - between the "unfortunate fact" of increasingly complex civil proceedings (in turn resulting from the "increasing complexity of our modern law and modern society" in a globalized economy ${ }^{5}$ ) and a continued need to make justice accessible - has resulted in a wide array of civil justice reform initiatives around the common law world over the past $10-15$ years. Included as significant components of these access to justice initiatives have been proposals for the expanded development and teaching of dispute resolution methods that are alternative to traditional processes of civil litigation.

For example, the Canadian Bar Association's Task Force on Systems of Civil Justice (CBA Task Force) was created in the spring of $1995 .^{6}$ Its focus, in the overall spirit of access to justice, was the modernization of the Canadian civil justice system. As part of its study and recommendations, the CBA Task Force specifically contemplated alternative dispute resolution (ADR) ${ }^{7}$ and its teaching in Canada. In its report, while commenting favourably on

1 Hon. Mr. Justice George W. Adans \& Naomi L. Bussin, “Alternative Dispute Resolution and Canadian Courts: A Time For Change" (1995) 17 Advocales" Q. 133 at 157 ["A Time for Change"].

: Ri. Hon. Brian Dickson, P.C., "Access to Justice" (1989) 1 Windsor Rev. Legal Soc. Issues I at 2 ["Access to Justice"], cited on CFCJ Homepage, ontine: CFCJ <www.cfcj-fcjc.org/quote.htm>.

lbid.

Ibid.

5 Elsewhere I have discussed glubalization in the context of the civil cours and the civil justice process: see Trevor C.W. Farrow, "Globalization, International Human Rights, and Civil Procedure" (2003) 41 Alta L. Rev. 671 at 687-90 ["Globalization, International Human Rights, and Civil Procedure").

" For the report and recommendations of the CBA Task Force, see Canadian Bar Association, Task Force on Systems of Civil Justice, Systems of Civil Justice Task Force Report (Ottawa: Canadian Bar Association, 1996) [CBA Task Force Reporf].

7 As I have discussed elsewhere with respect to the plrase "alternative dispute resolution":

There is significant debate over the meaning of ADR. As Andrew J. Pirie has commented when referring $10 \mathrm{ADR}$. "there continues to be a complicated fascination with what lies behind these three words." Alternative Dispute Resolution: Skills, Science, and the Law (Toronto: Inwin Law, 2000) at I [Skills. Science, and the Law]. Part of this debate stems from the recognition that, given its prevalence, ADR is no longer "alternative." Many theorists and practitioners now refer to ADR, in its current form, simply as "Dispute Resolulion" or "DR." Set e.g. ... Julie Macfarlane et al., eds., Dispute Resolution: Readings and Case Studies, 2d ed. (Toronto: Emond Montgomery, 2003) [Readings and Case Studies]. See also Stephen B. Goldberg et al, eds., Dispute Resolution: Negotiation. Mediation, and Other Processes, 4th ed. (New York: Aspen Law \& Business, 2003) 
what had already been accomplished, the CBA Task Force found a need for further work in the area of ADR and legal education. Specifically, it identified a need to review current ADR offerings by law schools, bar admission courses and continuing legal education providers to ensure that ADR "training and educational opportunities are widely available." CBA Task Force specifically recommended that "law schools ... offer education and training on dispute resolution options and on the means by which they can be integrated into legal practice, and ... [that] such courses [should] be mandatory in Canadian law schools and Bar admission course programs."

More than a decade after former Dickson C.J.C.'s comments were made, much has happened. Much, however, is still to be done. The purpose of this article is to look at our progress in the area of ADR teaching and research ${ }^{10}$ over the past number of years, primarily in light of various justice system reform initiatives in Canada. Specifically, in the underlying context of an ongoing responsibility to make justice more accessible for all members of society, this article explores the landscape of ADR education - primarily at law schools and makes proposals for continued thinking and reform.

Before beginning, a few words on my approach, research and perspective in this article. Given the significant and ever expanding amount of discussion that is currently occurring in the area of ADR," my approach to this article was necessarily broad. To facilitate this approach, the research was equally far-reaching and included both a comprehensive background literature review ${ }^{12}$ as well as an online $e^{13}$ and survey-based ${ }^{14}$ examination of

[Negotiation. Mediation, and Other Processes]: John S. Murray, Alan Scoll Rau \& Fdward F Sherman, Processes of Dispute Resolution: The Role of lawyers. $3 \mathrm{~d}$ ed. (Westbury. NY: The Foundation Press, 2002) |Role of Lawyers].

Trevor C.W. Farrow, “Thinking About Dispute Resolution," Review Essay (2003) 41 Alberta L. Rev. 559 at 559, n. 1 ["Thinking About Dispute Resolution"|. See also Trevor C.W. Farrow, "Negotiation. Mediation, Globalization Protests and Police: Right Processes; Wrong Systcm, Issues, I'arties and Time" (2003) 28 Queen's L.J. 665 at 688-89, nn. 90,94 ("Negotiation, Mediation, Globalization Protests and Police"]: "A Time For Change," supra note 1 at 135-41; Alison E. Gerencser, "Alternative Dispule Resolution Has Morphed Into Mediation: Standards of Conduct Must Be Changed" (1998) 50 Fla. L. Rev. 843 at 844-46; Alberta Law Reform Institutc (AI.RI), Consultation Memorandum No. 12.6, "Promoting Early Resolution of Disputes by Settlement" (Edmonton: ALRI. July 2003) at 9-10, online: ALRI Homepage <wnw.law.ualberta.ca/alri/pdis/cnslt_memo/cm12.6.pd/> ["Promoting Early Resolution of Disputes"]. In this article - for simplicity and consistency - I usc the term "ADR" as it "has come to be commonly used in legal scholarship and practice." ("Thinking About Dispute Resolution," ibid. at 559, n. 1).

- CBA Task Force Report, supra note 6 at 64

- Bbid. at 65, Recommendation 39.

I'I I have briefly commented elsewhere on the status of ADR researcl in Canada. See "'Jlhinking About Dispute Resolution," supra note 7.

$"$ See ibid. at 559-60.

12 The literature review specifically included: (a) a general review of the ADR movement; (b) government recommendations; (c) bar and law reform initiatives; (d) judicial commentary; and (e) academic literature on the topic of teaching dispute resolution. For a bibliography, designed to be used in the context of ADR course creation and review, see lirevor C.W. Farrow. "Dispute Resolution and Legal Education: A Bibliography" (2005) [unpublished, archived with author].

11 The online research - conducted primarily between July and October 2003 (and subsequently, although not comprehensively, updated) - included a review of: (a) publicly-availabie online curricular ADR materials from all common law Canadian law schools and selected U.S., U.K.. Australian and New Zealand law schools; and (b) a review of several non-law faculty, university and non-universitybased ADR programs in Canada. Given the varying levels of currency and coverage of thesc online materials (some institutions are simply betler than others at keeping their online materials 
current institutional approaches to ADR. ${ }^{15}$ In light of this extensive research, I hope that this article will act as a leading resource to assist in the ongoing, collaborative development of dispute resolution initiatives in legal education in Canada and abroad. Finally, in terms of overall perspective, my extensive and positive examination in this article of ADR as one potential tool in the project of increasing access to justice should not be taken as a full, uncritical endorsement of ADR generally. As will be discussed briefly later in the article, it is not. ${ }^{16}$

\section{Dispute. Rrsol.uTion AND Civil Justice. ReForm Initiatives}

\section{A. BACKGROUND}

As I have noted elsewhere, negotiation, mediation and other ADR processes are not new dispute resolution techniques. ${ }^{17}$ They have been employed in the context of various legal, political and other disputes at least since the time of Homer. Having said that, the modern ADR movement - as a well-established alternative to public civil justice options - is a

comprehensive and current), this aspect of the research is admittedly only as accurate as the original sources.

Trevor C.W. Farrow, "University of Alberta, Faculty of Law, Alternative Dispute Resolution Project: Survey" (29 September 2003) [unpublished] ["ADR Survey"]. The "ADR Survey" invited comments on the issucs discussed in this article from: (a) ADR instructors at all common law faculties of law in Caulada and other selected non-Canadian law schools; (b) selected instructors from non-law faculties in Canada; and (c) other interested stakeholders including selected judges and dispute resolution and law reform researchers. It was followed-up by an informal consultation process. By way of design, although conducled with ethics approval from the University of Alberta, Faculty of Arts, Science \& Law Research Ethics Board. the "ADR Survey" was never anlicipated to be statistically comprehensive. In order to avoid identilying certain participants (not all participants consented to the public use of their name), no comprehensive list of participants or results is included in this article. However, I can report that 15 survey responses were received, specifically from: (a) academics from six Canadian law faculties; (b) Frank Sander from Harvard Law School; (c) lan Macduff from Victoria University of Wellington, New Zealand: and (d) two other policy-oriented researchers. Further comments were also received from members of the Canadian judiciary and government. Where appropriate, reference to specific "ADR Survey" results is included from time to time in this article.

For a discussion of an carlier survcy of Canadian law schools conducted by the Canadian Bar Association (CBA), sec CBA, Commiltee Responding to Recommendation 49 of the Systems of Civil Justice Task Force Report (Ottawa: CBA, 1996); "Attitudes-Skills-Knowledge: Proposals for Legal Education to Assist in Implementing a Multi-Option Civil Justice System in the 2 I st Century" (Outawa: CBA, August 1999) at 5 ["CBA Survcy"] (this was a discussion paper that formed the basis of the CBA, Joint Multi-disciplinary Committec on Legal Education, Allitudes-Skills-Knowledge: Recommendations for Changes to Legal Education to Assist in Implementing Mulli-Option Civil Justice Systems in the 2/st Century (Ottawa: CBA, 2000) [Atuitudes-Skills-Knouvledge]). See further Attitudes - Skills - Knowledge, ibid. at 20-25.

For a discussion of similar U.S. surveys conducted by the American Bar Association (ABA), see e.g. Robert B. Moberly, "Introduction: Dispute Resolution in the Law School Curriculum: Opportunities and Challenges" (1998) 50 Fia. L. Rev. 583 at 585-86 |"Opportunities and Challenges"].

Although restorative justice is playing an increasingly important role in the Canadian justice system particularly as a "dispute resolution" $100 \mathrm{l}$ in the criminal context - this article primarily foeuses on dispute resolution in the civil justice system. However, given the importance of restorative justice and its potential as both a criminal and civil justice lool, brief reference is made to it in this article in the context of future teaching initiatives (see infra notes 334.51 and surrounding text), as well is in the context of recent work done by the Law Cummission of Canada (see infra notes 59-61 and surrounding (text). I am grateful to Michaela Keet for comments on this issue.

16. See infra Part VI.C.I.

17 See "Negotiation, Mediation, Globalization Protests and Police," supra note 7 at 667. 
comparatively new development. ${ }^{18}$ As recently as thirty years ago, ADR was described as a "relatively obscure" concept."

Today, ADR has now become part of the mainstream diet of American and Canadian practitioners and academics. As one recent source noted, "[t]here is a growing sense ... that it is time to look beyond adjudication as a single model for dispute resolution, and to consider instead a spectrum of dispute resolution alternatives." ${ }^{20}$ Students, lawyers, retired judges and other professionals are increasingly seeking meaningful ADR-related careers. ${ }^{21}$ Further, courts at all levels are both sanctioning and at times mandating this trend. ${ }^{22}$ As a result, as one U.S. commentator recently noted, the American Bar Association (ABA) "Section on Dispute Resolution Conference, only three years old, is larger than the ABA

1" For brief historical discussions, sce e.g. Warren E. Burger, "Isn'l Tluerc a Better Way?" (1982) 68 A.B.A. J. 274: Brian Dickson. "ADR. The Courts and The Judicial System: The Canadian Context" (1994) 28 L. Soc'y Gaz. 231 at 236 ["ADR, The Courts and The Judicial System"]. For general historical and contextual summaries, see e.g. George W. Adams, Mediating Justice: Legal Dispute Negotiations (Toronto: $\mathrm{CCH}$ Canadian, 2003) at 12-15; D. Paul Emond, "Alternative Dispute Resolution: A Conceptual Overview" in D. Paul Emond, ed., Commercial Dispute Resolution: Alternatives to Litigation (Aurorn, ON: Canada Law Book, 1989) 1 ["A Conceptual Overview"]; Skills, Science, and the Law, supra note 7 at 1-33. See also Carrie Menkel-Meadow, "Introduction: What Will We Do When Adjudication Ends? A Brief Intellectual History of ADR" (1997) 44 UCL.A L. Rev. 1613. ABA. Report of the American Bar Association Working Group on Civil Justice System Proposals, $A B A$ Blueprint for Improving the Civil Justice System (Chicago: ABA. 1992) at 31 [ABA Blueprint]. See futther the ABA, Just Solutions: Seeking Innovation and Change in the dmerican Justice System, by Stephen P. Johnson (Chicago: ABA, 1994) [Just Solurions]. For a uscful introduction to the rise of ADR in the United States, together with helpful source references, see "Opportunities and Challenges," supra note 14 at 584-85.

21 Readings and Case Studies, supra note 7 at xvii. Another commentator similarly described the current situation: "I see ADR as having become a part of the judicial system, perhaps inevitably and certainly for the present. Regardless of the effectiveness of ADR in particular situations, there is no doubt that socio-political forces will continuc to promote it and will not be turned back by a call for adoption of (or a return to) a greater use of traditional, full-dress adjudication of disputes" (Jeffrey W. Stempel, "Reflections on Judicial ADR and the Multi-Door Courthouse at Twenty: Fait Accompli, Failed Overture, or Fledgling Adulthood?" (1996) II Ohio St. J. Disp. Resol. 297 at 305-306 [citations omited] ["Reflections on Judicial ADR"]). See further Stephen N. Subrin. "A Traditionalisı looks at Mediation: It's Here to Stay and Much Better than I Thought" (2002/2003) 3 Nev. I.J 196.

"See "Thinking $A$ bout Dispute Resulution," supra nute 7 at 559 . Sec also Skills. Science, and he Law, supra note 7 at 394-98.

22 In the Supreme Court of Canada, for example. L.cBel J. recently staled, when referring specifically to arbitration, that it is, "in a broader sense, a part of the dispute resolution system the legitimacy of which is fully recognized by the legislative authorities" (Desputeanrv. Editions Chouetre (1987) inc., [2003] I S.C.R. 178 at para. 41). In terms of the modern, expansive role of the advocale, Gonthicr J. stated in Fortin v. Chretien, [2001] 2 S.C.R. 500 at para. 53, that:

[C]ontrary to popular belief, not only will a good advocate not foment dissension and promote disputes between parties, he will seek to reconcile opposing interests in order to avoid the ultimate confrontation of a trial. He will be called on to play the role of moderator. negotiator and conciliator. Indeed, it is his duty to facilitate a rapid solution to disputes and to avoid fruilless or frivolous actions.... Thus, whenever it is appropriate to do so, the advocate must discuss alternative dispute resolution methods (mediation, conciliation and arbitration) with his client, and must properly advise the client regarding the benefits of settling disputes. He may also hold discussions with the opposing party and negotiate a resolution of the dispute between the parties.

For comments on the importance of negotiation in the context of just settlements in the area of Aboriginal law, see e.g. Delgamuskw v. British Columbia, [1997] 3 S.C.R. 1010 at para. 186, Lamer C.J.C. For comments on the importance of alternatives to judicial determinations, specifically in the context of labour law, see e.g. Reference Re Public Service Employee Relations Act. Labour Relations Act and Police Officers Collective Bargaining Act. [1987] I S.C.R. 313 at 416-17. McIntyre J. 
Litigation Section Conference."23 Put simply, the face of the legal profession - and in particular the way modern disputes are thought about and resolved - has dramatically changed in Canada and around the world over the past decade. ${ }^{24}$

There are a number of reasons cited for this ADR "explosion." 25 Speed, efficiency, cost, privacy, flexibility, choice of decision-maker, increased comfort with the processes, elc. are all familiar benefits. However, the primary basis for the development of ADR that I am looking at in the context of this article stems from the view that providing alternatives through both court and non-court-based ADR initiatives - will provide civil justice system consumers with various cost-effective options that, ultimately, will increase overall access to the civil justice system. ${ }^{26}$ As former Chief Justice Brian Dickson commented, "if ADR is handled carefully, then it holds the potential for substantial improvements to the manner in which justice is delivered in Canada."27 It is for this reason that ADR has been a significant focus of various major Canadian reform initiatives developed over the past decade. ${ }^{28}$

Lela Porter Love, "Twenty-Five Years later with Promises to Keep: Legal Education in Dispute Resolution and Training Mediators" (2002) 17 Ohio St. J. Disp. Resol. 597 at 601 ["Twenty-Five Years l.ater with Promises to Keep"I.

The Canadian ADR movement has developed more slowly than its counterpart in the U.S., which has a "much longer and more established history of institutionalized ADR programs" (Readings and Case Siudies, supra note 7 at xvii). However, following the trends of our American ncighbours, ADR has similarly started to mushroom in Canada over the past number of years. For general comments, sec e.g. Julic Macfarlane, "What Does the Changing Culture of Legal Practice Mean for Legal Education?" (2001) 20 Windsor Y.B. Access Just. 191 at 191.92 ["Changing Culture"].

$\therefore \quad$ Put another way, the "lawyer's standard philosophical map" as described by l.conard Riskin is starting to change. See Lconard L. Riskin, "Mediation and Lawyers" (1982) 43 Ohio St. L.J. 29 at 43-44, cited in James R. Coben. "Summer Musings on Curricular Innovations to Change the L.awyer's Standard Philosophical Map" (1998) 50 Fli. L. Rev. 735 at 735.

2s Many people have relerred to the increased interest in ADR processes as an "explosion." See e.g. "ADR, The Courts and The Judicial System," supra note 18 at 231.

:to The phrase (or concept) "increasc[ing] ... access to ... civil justice," when used in this article, generally contemplates the basic factors identified in the CBA Task Force Report as "central" to improving access to the civil justice system: increased "speed," "affordability" and "public understanding." See e.g. CBA Task Force Report, supra note 6 at 11-12. For a recent discussion on "access to justice" and the importance not only of "formal equality of access" but also of "effective cquality of access" (particularly in the context of adequate representation), see Barrett v. Lay/on (2004), 69 O.R. (3d) 384 at 392 (Sup. (.. J.). lior a recent collection of discussions on the issue of access to justice, see Janet Walker, ef al.. eds., The Civil Litigation Process: Cases and Materials. 6th ed. (Toronto: Emond Montgomeny, 2005) at 162-98 [The Civil Litigation Process].

"ADR, The Courts and The Judicial System," supra nole 18 at 242. Similarly, as one of the early judicial proponents of ADR in the context of our modern juslice system - Justice George W. Adams, then of the Ontario Court of Justice (General Division) - has stated:

The problems aflicting the traditional court system stem from its total dependence on one dispute resolution mechanism. A more comprehensive dispute resolution response is required. Today many Canadians cannot afford a trial which means they cannot afford to have a dispute! ADR provides a necessary supplement to the traditional litigation process and builds on both previous court initiatives and the strengl/ss of the legal profession. Most important, for the 21 st century, $A D R$ can restore the role of our courts as community centres for conflict resolution and thereby foster values fundamental to the well-being of contemporary Canadian society ("A Time for Change," supra note I at 157).

: For background commentary, sec e.g. Jean Cumming. "CBA pushing for ADR training and standards: No uniformity in teaching or curriculum for practitioners" Lay Times (13 March 2000) 15. Sec also Ronit Dinovitzer \& Jeffrey S. Lcon. "When Long Becomes Too Long: Legal Culture and Litigators" Views on Long Civil Trials" (2001) 19 Windsor Y.B. Access Just. 106; Hon. Mr. Justice Warren K. Winkler, "Class procecdings and ADR: Synergies in a civil action" (2001) 20:3 Advocates' Soc. J. 3. 


\section{B. INTERNATIONAL CONTEXT OF REFORM}

Before looking at some of these Canadian initiatives, it is important to recognize - for purposes of contextualization - that Canada is certainly not the first common law jurisdiction to identify ADR as a tool of increasing importance in the ongoing worldwide effort to make civil justice more efficient and accessible. ${ }^{29}$

The first systematic modern ADR-related initiative, in the context of civil justice reform, came in the United States (where the modern ADR movement finds its roots). Following the 1976 Pound Conference on improving the administration of justice, the ABA established a dispute resolution committee in 1977. This committee was essentially designed to look into the growing importance of alternative processes for the efficient delivery of justice. ${ }^{30}$ It was at this time that our current court-based and other ADR-related reform initiatives really took off.

Approximately a decade later, the ADR movement in the U.S. was described as "dramatically different." During that period, the ABA had established goals to "integrate dispute resolution into every aspect of the legal system and society." specific focus on teaching, the ABA - in its seminal MacCrate Report on legal education and professional development ${ }^{33}$ - advocated strongly for an increase in practical, clinical courses and approaches at law schools designed to "address the lack of competence among graduating lawyers." 34 Included in its recommendations for increased training in lawyer skills was a focus on negotiation and litigation and alternative dispute resolution procedures. ${ }^{35}$ An

For a discussion of current and future trends, see Judith Resnik. "Procedures' Projects" (2004) 23 C.J.Q. 273.

For a useful resource identifying a number of reform initiatives in the areas of dispute resolution. access to justice, and law teaching, see generally "Symposium: Dispute Resolution in the Law School Curriculum: Oppontunities and Challenges" (1998) 50 Fla L. Rev. 583-865 ["Symposium: Dispute Resolution in the Law School Curriculum"].

Sec ABA Blueprint, supra note 19; Just Solutions, supra nole 19.

ABA Blueprint, ibid. at 31.

Ibid. For example, between 1988 and 1989, the ABA adopied resolutions: "[I]o promote continued use of and experimentation with ADR. both before and after suit is filed. as welcome components of the justice system" (adopted August 1989); and "[t]o support the increased use of ADR by federal agencies. which included support for the recently passed Administrative Dispute Resolution Acl of 1990" (adopted August 1988) (ibid. at 35).

ABA. Section on Legal Education and Adnissions to the Bar. Legal Education and Professional Development - An Educational Contimum. The Report of the Task Force on l.aw Schools and the Profession: Narrowing the Gap (Chicago: ABA, 1992) (Cllair: Robert MacCrate) [MacCrate Report]. For earlier $A B A$ teaching initiatives in the context of the development of $A D R$, see e.g. ABA. Section on Legal Education and Admissions to the Bar, Report and Recommendations of the Task Force on Lanyer Competency: The Role of Law Schools (1979) al 3-4: ABA. Lani. Schools and Professional Education: Report and Recommendations of the Special Committee for a Study of Legal Education of the American Bar Association (1980) at 103. both cited in "Opportunities and Challenges." supra note 14 at 585 .

Russell Engler. "The MacCrate Report Turns 10: Assessing its lmpact and Identifying Gaps We Should Seek to Narrow" (2001) 8 Clinical L. Rev. 109 at I1 5 ["The MacCrale Report Turns 10"]. Sec lurther Daniel Gordon. "Does Law Tenching Have Meaning" Teaching leffectiveness. Gaugung Alumnı Competence, and the MacCrate Report" (1997) 25 Fordham Urb. 1... 43.

ss See MacCrate Report, supra note 33 at 138-40, cited in "The MacC Crate Report Turns 10." thid at I1,3. n. 13, and further in Robern MacCrate. "Yesterday, Today and Tomorrow: Building the Continuum of Legal Educalion and Professional Development" (New York 1,aw School. Clinical Rescarch Institute. 
underlying basis for this focus, according to the ABA, was that it "understands that continued public and professional education about ADR is necessary to aid in the transformation of a legal system now centered around litigation into a system that includes non-adversarial ADR mechanisms. ${ }^{36}$ Other reform related ADR initiatives - at both the federal ${ }^{37}$ and state ${ }^{38}$ levels - continued to develop in the U.S. after the publication of the 1992 MacCrate Report. ${ }^{39}$

Research Paper Series No. 03/04-1, Seplember 2003) at 3, n. 6, online: Social Science Research Network Electronic Paper Collection <hitp://papers.ssrn.com/sol3/papers.cfim?abstract_id=444601> ["Yesterday, Today and Tomortow"].

$A B A$ Blueprint, supra note 19 at 39 . As a result, the $A B A$ actively "promote[d] greater awareness of ADR through its publications, conferences, workshops and seminars" (ibid. at 38). In fact, as the ABA itself commented, in the context of its consideration of the report of the President's Council for Competitiveness (President's Council on Competitiveness, Agenda for Civil Justice Reform in America (Washington, D.C., 1991)), it was "the prime mover in the creation of the Multi-Door Courthouse" (ABA Blueprint, ibid. at 35). (The concept of the "Multi-Door Courthouse" was developed in 1976 by Frank Sander of Harvard Law School. See ibid. at 36. See also Frank E.A. Sander, "Varieties of Dispute Processing" (1976) 70 F.R.D. III, cited in Skills, Science, and the Law, supra note 7 at 396: "Reflections on Judicial ADR," supra note 20).

17 For example, on 5 February 1996, the President signed Exccutive Order 12988 on Civil Justice Reform. The Preamble to Title 3 of the Order highlights the Federal Government's intention "to improve access to justice for all persons who wish to avail themselves of court and administrative adjudicatory tribunals to resolve disputes, to facilitate the just and efficient resolution of civil claims involving the United States Government, ... to promote fair and prompt adjudication before administrative tribunals, and to provide a model for similar reforms of litigation practices in the private sector and in various states." EO 12988 - Civil Justice Reform, 66 Fed. Reg. $4727-4734$ (1996), Title 3, p. 4729, s. I, revoking EO 12778, 56 Fed. Reg. 55195 (1991), supplemented by EO 13083, 63 Fed. Reg. 27651 (1998) (which was suspended by EO 13095, 63 Fed. Reg. 42565 (1998)); EO 13132, 64 Fed. Reg. 43255 (1999). The Order, among other things, provides that in the context of civil litigation involving the federal government in federal courts, ADR processes should be canvassed "[w] henever feasible"; EO 12988, ibid. at Title 3, p 4729, s. I(c)(1). Further, to "facilitate broader and effective use of informal and formal ADR methods," the Order provides that "litigation counsel should be trained in ADR techniques"; ibid. at Title 3, p. 4729. s. 1(c)(3). Finally, it is important to note that, although outside the specific federal government mandate, the Order expressly contemplates acting as a "model" for litigation reform in both the private sector and in the various states; EO 12988, sbid. at Title 3, p. 4729. s. 1. For a general discussion, see e.g. Jeffrey M. Senger, "Turning the Ship of State" [2000] J. Disp. Resol. 79.

For a somewhat similar initiative in Canada, see, for example, the Dispute Resolution Centre for Excellence (DRC) established by the Department of Justice in 1992. The DRC - "devoled to the prevention and management of disputes" in Canada - has a mandate "lo serve as a leading centre of DR excellence in Canada"; DR Centre for Excellence. "DRS Programs and Services," online: Department of Justice <ittp://canada.justicc.gc.ca/en/ps/drs/drs_programs.html>. The DRC's stated role is "to promote a greater understanding of DR and assist in the integration of DR into the policies, operations and practices of departments and agencies of the Government of Canada, Crown Corporations, federal tribunals and administrative agencies, and federally constituted courts" (ibid.). For a review of state bar association ADR initiatives, see e.g. ABA. Section of Dispute Resolution, State and Local Bar Alsernative Dispute Resolution Survey, 200/ Edition (Washington: ABA, Section of Dispute Resolution, 2001), online: ABA <www.abanet.org/statelocal/summaryreport.pdP. For specific state initiatives, see e.g. Judge H.J. Fromholz, "The Los Angeles Superior Court Mediation Program" (Cconference presentation, Calgary, Alberta, 18 October 200I) in CFCJ el al, eds., "Negotiating the Future: A National Conference on Court-Annexed Mediation" (Calgary, Alberta, 15 November 2001) [unpublished conference materials] ["Negotiating the Future"]; Sharen Press, "Florida Court-Connected Mediation Programs" (Conference presentation, Calgary, Alberta, 18 October 2001), in ibid. [unpublished]; "Reflections on Judicial ADR," supra note 20.

iy $\quad$ For general discussions, see e.g. "Yesterday, Today and Tomorrow," supra note 35; "The MacCrate Report Turns 10," supra note 34; Douglas S. Adams, "Alternative Dispute Resolution Programs in Law School Curricula - What's Next?" (A project for the ABA Section of Dispute Resolution, 24 August 2001), online: ABA <www.abanet.org/dispute/adamspaper.pdß. 
Four years after the 1992 publication of the MacCrate Report in the U.S., Lord Woolf's extensive reform-based study on access to justice was published in the United Kingdom. ${ }^{40}$ The Woolf Report generally provided an expansive review and set of recommendations for increasing access to civil justice. Further, it specifically considered the importance of ADR initiatives as tools for increasing access and efficiency. For example, when describing the "new landscape" of reformed civil justice, Lord Woolf stated that litigation "will be less adversarial and more co-operative." As such, the "court will encourage the use of ADR ... and will take into account whether the parties have unreasonably refused to try ADR or behaved unreasonably in the course of ADR."Al This report was certainly the international study that was most influential in terms of subsequent civil justice reform thinking in Canada. ${ }^{42}$

Finally, civil justice reform in Australia has also been influential in the context of recent Canadian reform projects. Australia starts with the proposition, as do other jurisdictions, that most law suits settle: ${ }^{43}$

As the empirical data ... confirms, the vast majority of civil disputes commenced with in the federal court and tribunal system are concluded by means other than formal adjudication... They are settled by negotiation or through other dispute resolution mechanisms (such as mediation, conciliation or arbitration) or diseontinued by the initiating party. ${ }^{44}$

Given these settlement realities, and further, given the use that can be made of specific ADR initiatives in the context of making justice more efficient and accessible, the Australian Law Reform Commission looked at the importance of education in promoting ADR initiatives. For example, the Commission made very useful comments on the importance of ADR in law faculties:

If law teaching placed greater emphasis on the role of lawyers as dispute managers and resolvers, as facilizators of harmonious legal relations, and as legal communicators who presented clients with an array of methods by

Lord Woolf, Access to Justice: Final Report to the Lord Chancellor on the Civil Justice System in England and Wales (London: HMSO. 1996) (Woolf Report).

Ibid. at 4-5. Sec also ibid. at 16-17.
For general discussions of the WolfReport, see e.g. Joshua Rosenberg. "Alternative Dispute Resolution in Public Law: Interview with Lord Woolf, C.J. Conducled by Joshua Rosenberg" in Richard Gordon. ed., Judicial Review in the New Millennium (london: Sweet \& Maxwell, 2003) 109; Suzanne Burn. "The Civil Justice Reforms in England and Wales: Will l.ord Woolf Succeed Where Others Have Failed?" (1999) 17 Windsor Y.B. Access Just. 221.

As Paul Emond has noted, "the vast majority (95\% $1098 \%)$ of disputes are resolved through negotiation and not adjudication" ("A Conceptual Overview," supra note 18 at 3). For a summary of these trends, see e.g. Julie Macfarlane, "Why Do People Settle?" (200I) 46 McGill L.J. 663 at 665 . See also "Promoting Early Resolution of Disputcs," supra note 7 at 8, n. 17, which indicates that the "current ralio of trials to filings in ... Canadian and foreign jurisdictions" is "less tha[n] $2 \% . "$

Australian Law Reform Commission (ALRC),"Review of the Federal Civil Justice Syslem," Discussion Paper 62 (1999) at c. 3, para. 3.40 [footnotes omilted, online: Al.RC <www.austlit.edu.aw au/other/alrc/publications/dp/62/> ["Al.RC Discussion Paper"]. See further the ALRC . Managing Justice: A Review of the Federal Civil Jistice System, Report No. 89 (Sydney: ALRC, 1999), online: ALRC <uww.austlii.edu.au/au/other/alrc/publications/reports/89/>; Murray Gleeson. "Managing Justice in the Australian Context" (Sydney: ALRC, 2000). 
which disputes could be resolved, this could address perceived problems in the adversarial system of litigation. ${ }^{45}$

\section{REForm IN CANADA}

The foundational report in Canada on the reform of its civil justice system is the CBA Task Force Report. ${ }^{\text {to }}$ The specific purpose of the CBA's study was "to inquire into the state of the civil justice system on a national basis and to develop strategies and mechanisms to facilitate modernization of the justice system so that it is better able to meet the current and future needs of Canadians." ${ }^{47}$

As part of that inquiry, the CBA Task Force specifically turned its mind to the role that alternative methods of dispute resolution can play in making the justice system more efficient and accessible. ${ }^{48}$ It is in this context that it proposed the development and encouragement of a "multi-option civil justice system." ${ }^{\text {"49 }}$ According to the CBA Task Force Report, in a multioption civil justice system, "litigation lawyers must move away from a focus on rights-based thinking and adopt a wider problem-solving approach." dispute resolution approach" to "litigation practice"st - was described by the CBA not only as desirable, but as a "new professional obligation."

To make this "fundamental shift in litigation practice,"'s significant training of lawyers is required, both for the benefit of lawyers themselves as well as for the benefit of the broader public. As the CBA Task Force acknowledged, "it is in the public interest as well as the interests of the profession to encourage the development of dispute resolution skills and to support them with institutional processes." 44 The CBA Task Force Report further provided that, in light of the public interest and the interests of the profession,

public expectations of lawyers in a multi-option civil justice system will be high. The education and Iraining opportunities available to law students and lawyers must reflect these changing expectations and

43 "ALRC Discussion Paper," ibid. at c. 3, para. 3.42.

th CBA Task Force Report, supra note 6. For carlier efforts to look at efficiencies in the Canadian courts, see e.g. the Zuber Commission Report: Ontario, Report of Ontario Cour's Inquiry, by T.G. Zuber (Toronto: Ontario Ministry of Attorney General, 1987); Hon. E.N. Hughes, Access to Justice: Report of the Justice Reform Conmillee (Victoria: Ministry of Attorncy General, 1988); Law Sociely of Upper Canada (LSUC), Alternatives - The Report of the Dispute Resolwion Subcommince (Toronto: L.SUC, 1993); Maniloba, Civil Justice Review lask Force, Maniloba Civil Justice Review Task Force Report (Winnipeg: Department of Justice, 1996) (Chair: David Newman); Ontario Civil Justice Review. Civil Justice Review: Supplemental and Final Reporf (Toronto: Ontario Civil Justice Review, 1996). CBA Task Force Report, ibid. at iii.

Ibid., summary of Task J:orce Recommendations 1-3, 5, 13, 26-27, 36, 38 and 49 at v-viii. For a discussion of the CBA Task Force Report recommendations, see e.g. ClCJ, "Civil Justice Reform Update" News and Views on Civil Justice Reform 2 (Fall 1999) 17. See also Skills, Science, and the Law, supra note 7 at 389.90 .

See e.g. CBA Task Force Report, ibid. at c. 4.

lbid. at 63.

lbid. at 64.

Ibid. IFor a discussion of the implications of this new "professional obligation" for lawyers in the context of future ADR research, see infra note 290 and surrounding lext.

CBA Task Force Report, ibid. at 64.

Ibid. at 63 . 
responsibilities... The time has come for a reassessment ... of the underlying principles of the teaching of law and for a redefinition of essential skills ... through improving, perhaps cven revolutionizing, legal education. ${ }^{\text {s5 }}$

Recognizing these various needs, interests and expectations, the CBA Task Force found that

lawyers will need to be educated about dispute resolution options and trained in their effective integralion into their practices. Some law scloools have already recognized the value of expanded training in these areas and now provide courses on dispute resolution techniques. In most instances, however, courses remain optional rather than mandatory. In addition, it is not clear at all to the Task Force that in traditional law scliool courses, sufficient emphasis is placed on a wider view of the lawyer's responsibility to achicve dispute resolution.

In the view of the Task Force, law schools, Bar admission course educators and continuing legal education providers all have a responsibility to ensure that these training and educational opportunities are widely available.... We ... encourage legal educators to review their programs ... to assess whether they provide sufficient opportunities for the development of dispule resolution skills. ${ }^{56}$

In light of these significant recommendations, the CBA Task Force Report was followed four years later, in 2000, by the CBA's Attiludes - Skills - Knowledge report." That report was generally a response to the CBA Task Force's Recommendation No. 49, which was in turn designed to consider the creation of a "legal education plan to assist in civil justice reform."

More recently, in 2003, the Law Commission of Canada looked further at the broad issue of dispute resolution in Canada in the context of restorative justice initiatives. ${ }^{39}$ With specific focus on the resolution of disputes and ADR, the Law Commission recommended that universities and colleges, "and law schools in particular," should "continue to expand the quality of teaching in alternative dispute resolution offered to law students...." ${ }^{160}$ Further, the Law Commission recommended that

- law societies make the provision of continuing education in alternative conflict resolution a priority. encourage their members to undertake such training and review their codes of professional conduct to ensure that the role of line lawyer as an advocate in restorative or consensus-based justice processes is adequately anticipaled; .... and

Ibid. at 72 [emphasis omitted].

5. Ibid. at 64 . The Report also contemplated, in Recommendation No. 39, making ADR courses mandatory at law schools and Bar admission courses. See ibid. at Recommendation No. 39. Supra note 14.

CBA Task Force Report, supra note 6 at 73. The CBA, in its Atuindes - Skills - Knowledge report, encouraged law schools to pursue these initiatives through "grealer interdisciplinary sludy and research on the operation of law as a primary means of peaceful conflict resolution" (supra note 14 at 48). Commission of Canada, 2003) [Transforming Relationships]. I am gratcful to Roderick J. Wood who first brought this report to my attention. 
businesses and voluntary organizations review their policies to ensure that employees' participation in participatory processes is considered in the same light as court attendance and that they continue to develop participatory justice projects to resolve conflicts within their organizations. ${ }^{61}$

Coming out of these national recommendations, including the Law Commission's recommendations and the 1996 recommendations contained in the CBA Task Force Report, together with various provincial initiatives, ${ }^{62}$ is a clear mandate for the increased consideration and use of ADR tools in the context of civil justice reform. Much has already been accomplished in this regard, particularly in the area of provincial court-connected ADR initiatives. ${ }^{63}$ Two examples of these initiatives - one quite different from the other -

Ibid.

Various provincial reform projects in Canada have, over the past 10-15 years, looked at options for reforming regional civil justice processes. In Ontario, see e.g. the various reform projects cited abuve (supra note 46). As another example, in the West, Alberta Justice sponsored a 2001 consultation session in Calgary that brought together ADR practitioners, court personnel, policy makers and academics. Behind this session was the provincial government's stated commitment "to improving access to courts and to simplifying our provincial justice system": Hon. Dave Hancock, "Message from Alberta's Minister of Justice and Attorney General" in Alberta Justice, "Alberta Justice's Consultation on CourtAnnexed Mediation (Consultation Brochure, Calgary, 16 November 2001) (archived with author] ["Alberta Justice's Consultation on Coun-Annexed Mediation"]. Like their national counterparts, many of these regional initiatives have also examined the use of ADR as a significant tool for addressing the "timeliness, affordability and complexity of civil court proceedings" ("Promoting Early Resolution of Dispules," supra note 7 at xiii). For example, the purpose of the 2001 Alberta consultation was to make recommendations to the Minister of Justice concerning dispute resolution alternatives, including possible court-annexed mediation prograns in civil cases. Sec "Alberta Justice's Consultation on CourtAnnexed Mediation," ibid. Coming out of these initiatives is a recent Alberta Justice "pilot initiative" that promotes "private, user pay, interest based mediation in Alberta": see Court of Queen's Bench of Alberta, "Civil Practice Note No. II: Court Annexed Mediation" (effective I September 2004), online: Alberta Courts <wnw.albertacourts.ab.ca/qb/practicenotes/civil/pnl ICourtAnnexedMediation.pdis ["Alberta Coun Annexed Mediation"]. Also in Alberta, ALRI comprehensively looked at judicial dispute resolution initiatives - in the context of its Alberta Rules of Court revision project - designed to promote early settlement of disputes in Alberta through the use of ADR tools. See "Promoting Early Resolution of Disputes," supra note 7. For a discussion of this recent Alberta study, see Margaret A. Shonc, "Alberta Rules of Court Project: Promoting Early Dispute Resolution Through Settlement" The Barrister 68 (June 2003) 18. See further Christine E. Hart. "Draft Model Guidelines for CourtConnected Mediation Programs" (Prepared for the CBA Systems of Justice Implementation Committee's Working Group on Dispute Resolution Standards, 3 September 1998); M. Jerry McHale. "Uniform Mediation Act: Discussion Paper" (Paper presented at the Uniform Law Conference of Canada, Victoria, B.C., August 2000), online: CFCJ. Civil Justice Clearinghouse <http://karl.srv.ualberta.ca/pls/portal30/Jaw.menu_search.show>; Julie Macfarlane \& Michaela Keet, Learning From Experience: An Evaluation of the Saskatchewan Queen 's Bench Mandatory Mediation Program: Final Report (Regina: Saskalchewan Justice, 2003), online: Saskalchewan Justice <www. saskjustice.gov.sk.ca/DisputeResolution/pubs/QBCivilEvaluation.pdf> [Learning From Experience]. For example, court-related ADR programs have been instituted in a number of jurisdictions in the country, including British Columbia, Alberta (discussed infra note 65), Saskatchewan, and Ontario (discussed infra note 64). For general summary discussions of these provincial initiatives, see e.g. "Cross Country Snapshot of Dispute Resolution" New's \& Views on Civil Justice Reform 4 (Spring 2002) 12 at 12-14 ["Cross Country Snapshot"]; Graeme A. Barry. "In the Shadow of the Rule of Law: Alternative Dispute Resolution and Provincial Superior Courts" News and Views on Civil Justice Reform 8 (Fall 1999) 2 ["In the Shadow of the Rule of l,aw"]; "Negotiating the Future," supra note 38; Palricia Hughes, "Mandatory Mediation: Opportunity or Subversion?" (2001) 19 Windsor Y.B. Access Just. 16] ["Mandatory Mediation: Opportunity or Subversion?"]; Joan I. McEwen, "JDR: Judicial Dispute Resolution" National (Canadian Bar Association), 8:7 (November 1999) 36; David Orr, "Alternative Dispute Resolution in the Canadian Court System" (1999) 19:2 The Court Manager 36; Michaela Keet \& Teresa B. Salamone, "From Litigation to Mediation: Using Advocacy Skills for 
include initiatives in Ontario ${ }^{64}$ and Alberta. ${ }^{65}$ In addition, a further mandate coming out of

Success in Mandatory or Court-Connected Mediation" (2001) 64 Sask. L. Rev. 57 ["From Litigation to Mediation"]. For specific commentary on B.C.'s initiatives, see e.g. Jill Leacock, "British Columbia Court of Appeal Judicial Settlement Conference Pilot Project" (2004) 62 Advocate (B.C.) 879; Gordon Turriff, "On the Road to Civil Justice Reform in British Columbia" (2004) 62 Advocate (B.C.) 863: Jack Giles, "The Compulsory Mediator" (2004) 62 Advocate (B.C.) 537. For an historical argument in favour of court-annexed ADR, see "A Time for Change," supra note I. For general comments on governmental reform interests, sec e.g. M. Jerry McHale, "8 Minutc Round Table," in Justice Institute of B.C. et al., eds., "Shaping Directions in Policy, Research and Pedagogy." The First Annual B.C. Symposium on Conflict Resolution (Conference Materials, Vancouver, B.C., 25 April 2003) ["Shaping Directions"]. Further, in terms of specific areas of law, ADR has taken strong hold with respect to family law matters in Canada, including custody, access, guardianship and child welfare. See e.g. "Cross Country Snapshot," ibid. See also recently Marion Boyd, "Dispute Resolution in Family Law: Protecting Choice, Promoting Inclusion" (December 2004), online: Ontario Ministry of the Attorney General <www.attorneygeneral.jus.gov.on.ca/english/aboul/pubs/boyd/fullireport.pd [> ["Boyd Report"]. For recene commentary on the "Boyd Repon," see John Jaffey, "Boyd report draws mixed reaction" The Laniyers Weekly (21 January 2005) 9; Faisal Kutly, "Commentary: Boyd's recommendations balance needs of religious communities with rights of vulnerable" The Leanyers Weckly (21 January 2005) 9. Over the past five years, Ontario has developed, in certain specific urban centres, a court-connected ADR initiative. The approach in Ottawa and Windsor (and until very recently Toronto, see below) entrenched in r. 24.1 of Ontario's Rules of Cwil Procedure - involves a mandatory mediation program applicable to most case-managed and other cases. This process. requiring parties to submit to a mediation service run by private, roster-based mediators, has by and large been very successful. According to Justice Chadwick of Ontario's Superior Court of Justice. "[i]n my view, mandatory mediation and case management is here to stay" (Hon. Mr. Justice James B. Chadwick, "Court-Annexed Mediation in our Civil Courts" (14 November 2001) at II in "Negotiating the Future," supra note 38 [unpublished]). For a summary of the program and related links, see "Mandatory Mediation Program," online: Ontario Ministry of the Attorney General < www. attorneygeneral.jus.gov. on.ca/english/courts/ manmed/>. See also Andrew C. Dekany, "Judges increasingly mediating in Ontario and Quebec" The Lanyers IVeekly (2I January 2005) 14. Although many have viewed the Ontario initiatives as helpfiul. there are numerous numbers of the Bar and Bench, particularly in Toronto, who have increasingly criticized its across-the-board application. Sec e.g. Martin Teplitsky, "Universal mandatory mediation: A critical analysis of the evaluations of the Ontario mandatory mediation program" (2001) 20:3 Advocates' Soc. J. 10; Martin Teplitsky, "Excessive cost and delay: Is there a solution?" (2000) 19:2 Advocales' Soc. J. 5: John Jaffey, "Memo suggests axing case management, mandatory mediation" The Lawjers Weekly (1 October 2004) 3; Jan Weir, "Mandatory mediation meltdown" The Lanigers Weekly" (8October 2004) 6. See also generally "Mandatory Mediation: Opportunity or Subversion?," supra note 63: Hon. Hugh F. Landerkin \& Andrew J. Piric, "Judges as Mediators: What's the Problem with Judicial Dispule Resolution in Canada?" (2003) 82 Can. Bar. Rev. 249. As a result of this rising criticism and calls for reform, a new practice direction - suspending the automatic operation of $r$. 24.1 in Toronto - has been published that revises the approach to $\mathrm{ADR}$ and case management in Toronto civil cases (pre-trial mediation is still mandalory in most cases). Sec Superior Court of Justice, Toronto Region. "Practice Direction - Backlog Reduction/Best Practices Initiative" (in effect 31 December 2004). online: Ontario Courts <www.ontariocourts.on.ca/superior_court justice/notices/casemanagement. him>.

6s In Alberta, by contrast, the Court of Queen's Bench. largely as a result of the initiatives of the Alberta judiciary, has developed a court-annexed Judicial Dispute Resolution (JDR) program. Although significantly different from Ontario's mandatory program, Alberta's voluntary, judge-run, relatively ad hoc JDR process has become exiremely active and successful. According 10 Belzil J. of the Alburta Court of Queen's Bench. "IoJver the last number of years JDR has become hugely popular in the Province of Alberta... L.awyers and clients report a high degree of satisfaction with the system, with ever increasing request for JDR" (Hon. Mr. Justice R. Paul Belzil. "JDR (Judicial Dispute Resolution)" (14 November 2001) at 7-8 in "Negotiating the Future," supro note 38 [unpublished]. Similarly, according to Wachowich C.J." "It]o say the least, it [JDR in Alberta] has been an overwhelming success" (Hon. Allan H. Wachowich, "Opening of the Court" (Calgary Courthouse, 2 September 2003) at 19-20 [unpublished] [archived with author]. Further, also in Alberta, ADR - largely in the form of mediation - is being used extensively in the Alberta Provincial Court. See Alberta Provincial Cours 
these reform projects involves the concomitant reform of legal education toward an increased awareness and use of ADR as a key part - or "necessity" according to one Ontario Court of Appeal judge ${ }^{66}$ - of the overall project of reforming Canada's civil justice system. It is a review of this educational project to which I now turn. ${ }^{67}$

\section{Dispute Resolution and Legal Education}

The face of the legal academy, like other justice system stakeholders, has also changed over the past three decades.$^{68}$ Included in this change are the teaching and research of dispute resolution, which have clearly taken on new and critical importance. ${ }^{69}$ For example, in American law schools in 1976, "there was no subject category for ADR or mediation." 1992, more than 94 percent of these schools offered dispute resolution courses. "And the trend did not stop then. Since 1999, "the level of interest in dispute resolution - and in particular in the teaching of dispute resolution - has risen exponentially."72 A 2002 American commentary indicated that "more than 500 law professors identify themselves as teaching ADR." A similar "exponential[]" increase in dispute resolution teaching has

Act, Mediation Rules of the Provincial Court, CivilDivision, Alta. Reg. 271/97. Finally, see the recently announced "Alberta Court Annexed Mediation" 2004 pilot project, supra note 62. For useful discussions of the current JDR initiatives in the Alberta Court of Queen's Bench, see Hon. John A. Agrios, A Handbook on Judicial Dispule Resolution for Canadian Lanyer. (Version I. I, January 2004), online: Canadian Bar Association - Alberta < www.cba.org/alberta/PDF/JDR\%20 Handbook.pdP: Hon. John A. Agrios, A Handbook on .Judicial Dispute Resolution for Law Students (Version 3.7, July 2003); "Promoting Early Resolution of Disputes," supra note 7 at 70-77; Hon. Jolın A. Agrios, A Handbook on Judicial Dispufe Resolution for Canadian Judges (Version 2.5., September 2002), cited in ibid. at 72, n. 175; "In the Shadow of the Rule of Law," supra note 63; "Negotiating the Future," supra note 38; Alberta Justice Annual Report 2002/03 (Edmonton: Alberta Justice Communications, 2003) at 19, online: Government of Alberta <www.solgen.gov.ab.ca/publications/ downloads/annual_report/2003/alberta_justice_annual_report_2003.pdf>. For a useful discussion of the Provincial Court's mediation program, see "Promoting Early Resolution of Disputes," ibid. at 54-59. According to Austin J.A., "until very recently, lawyers and judges in Canada were nol generally trained in negotiation, mediation or arbitration. Only in the last 10 years has instruction in alternative dispute resolution become a necessity amongst lawyers and judges across Canada" (Canadian Union of Public Employees v. Ontario (Minister of Labour) (2000). 51 O.R. (3d) 417 at para. 41 (C.A.)).

While it is recognized that education in ADR occurs at all levels of legal training and practice - at law schools, bar admission courses and continuing legal education courses (discussed further al infra note 89) - this paper focuses primarily on law school initiatives.

See e.g. Kenneth W. Acton, "The Impact of Mediation on Legal Education and on the Profession" (1999) 17 Windsor Y.B. Access Just. 256 ["The Impact of Mediation on Legal Education and on the Profession"].

"Changing Culture," supra note 23 at 192. See also "Thinking About Dispute Resolution," supra notc 7.

50 "Twenty-Five Years Later with Promises to Keep," stupra note 23 at 598 [foolnote omitted]. Sec also generally Frank E.A. Sander, "The Future of ADR" [2000] J. Disp. Resol. 3 ["Future of ADR"]. $A B A$ Blueprint, supra note 19 at 31.

" Readings and Case Siudies, supra note 7 at xvii. See further "Opportunities and Challenges," supra note 14 at 585-86.

7. "Twenty-Five Years Later with Promises to Keep," supra note 23 at $\$ 98$ [foolnote omitted]. Sec also generally "Future of ADR," supra note 70; Frank E.A. Sander \& Robert H. Mnookin, "A Worthy Challenge: The teaching of problem solving in law schools" Dispufe Resolution Magazine 6 (Summer 2000) 21. 
occurred in Canada. ${ }^{\text {" }}$ According to the "CBA Survey," "it is clear that there is increased interest in and emphasis on [A]DR in all law schools."

Further, this interest is not simply a top-down phenomenon. In fact, much of it is driven by student interests and demands. There is no doubt that students generally welcome courses - or at least parts of courses - that tangibly relate to the practice of law. As one report indicates, the growth of clinical legal education in the U.S. and subsequently in Canada stemmed, at least in part, from "student demands for relevance in the law school curriculum." 76 This demand includes courses in ADR." As Catherine Morris has rightly noted, "dispute resolution education is in hot demand by law students." ${ }^{\text {" }}$ For example, a poster of one of the most recently formed student groups at the University of Alberta - the "Student Arbitration and Mediation Society" - recently questioned: "ADR, the fastest growing trend in the practice of law, are you prepared?"79 Clearly there is an interest at the student level for ADR-related course initiatives.

In the next two parts of this article, I document how dispute resolution is currently being taught at all Canadian common law faculties of law, ${ }^{811}$ together with certain other selected Canadian and foreign law and related programs. The purpose of these two parts of this article is threefold: (a) to catalogue what makes up this "exponential" increase in ADR teaching; (b) to allow for critical thinking about how these current approaches to dispute resolution teaching and research match up to the various civil justice system reform proposals discussed above; ${ }^{81}$ and (c) to provide a framework for future comparative and collaborative curriculum review and reform.

See Readings and Case Studies, supra note 7 at xvii.

Altitudes - Skills - Knowledge, supra note 14 at 25. See also "The Impact of Mediation on L.egal Education and on the Profession," supra note 68 at 258-59: Catherine Morris, "The Moulding of Lawyers: ADR and Legal Education" (1999) 17 Windsor Y.B. Access Just. 271 at 272-73 ["The Moulding of Lawyers").

Margaret Martin Barry et al., "Clinical Education for this Millennium: The Third Wave" (2000) 7 Clinical L. Rev. I at 16, cited in "The MacCrate Report Turns 10." supra note 34 at I15, nn. 25-26. Eric Atkins, "Courses on ADR becoming popular in Canada's law schools" The Lawyers Weekly" (3 November 2000) 24.

"The Moulding of Lawyers," supra note 75 at 271.

University of Alberta, Student Arbilration and Mediation Society (Lecture Poster, 24 March 2003) [archived with author].

For an earlier effort in this regard, see Jonnette Watson I lamilion, "The Significance of Mediation for Legal Education" (1999) 17 Windsor Y. B. Access Just. 280 ["The Significance of Mediation for Legal Education"]. See also Michaela Keet, "Alternative Dispute Resolution. Curriculum Review Project" (College of Law, University of Saskatchewan, February 1997) [on file with author] ["Saskutchewan Review Project"]; Estee Garfin, Rachacl Iscove \& Julie MacLean, "How We Got to Yes: Introducing an ADR Practicum at the University of Toronto Faculty of Law" (April 2001), online: CFCJ <www.cfcj-fcjc.org/full-text/2001_dra/raphael_iscove.lıtml> ["How We Got to Yes"].

Supra Parts II-III. 


\section{Canadian Dispute Resolution Programs}

\section{A. BACKGROUND}

Canadian common law schools approach dispute resolution in a number of different ways. This variation was recognized by the "CBA Survey," be differences in the ways law schools deal with conflict resolution training, ranging from optional DR seminars, to clinical education for credit to mandatory exposure for all students." ${ }^{83}$ The literature review and "ADR Survey" conducted for this article ${ }^{84}$ confirmed and strengthened these earlier "CBA Survey" findings.

Further, different degrees of accuracy of institutional reporting, combined with a relative lack of consistency of course cataloguing, can be equally variable and problematic. ${ }^{85}$ Different institutions - and members of the civil justice system generally - have varying definitions for what counts as a course in "dispute resolution." As can be seen from the various program descriptions set out in Parts IV and $V$ of this article, some include only "ADR" and directly related courses; whereas others include a broader group of courses including more traditional "civil procedure"-type courses. As such, simply counting courses is likely' not a particularly useful or accurate method of evaluating a given institution's approach or commitment to dispute resolution. ${ }^{86}$

Given these differences in institutional approaches to ADR teaching in Canada, together with the range of approaches to, and accuracy of, institutional reporting, it is difficult to categorize with precision the various ADR programs and courses that make up those programs. In essence, however, there are essentially three basic models of dispute resolution programs in Canada: (a) university institutes/centres closely combined with law faculty courses; (b) integrated - "pervasive" ${ }^{\text {"7 }}$ - ADR approaches; and (c) "traditional" coursebased ADR programs. ${ }^{88}$ As will be discussed, some of these programs provide students with opportunities to take ADR courses in the context of dispute resolution "tracks" $"$ "streams"

*: Discussed supra note 14

"1 Attitudes - Skills - Knowledge, supra note 14 at 25.

nt Discussed supra notes 12-14.

ns The accuracy of the online rescarch conducted for this sarticle was discussed earlier, supra note 13.

st. I am gratefill to Michaela Keet lor comments on this issue.

"While the term "pervasive" - in the context of pedagogical approaches - is now widely used, my use of the term, and concept, continues to be influenced by Deborah Rhode's pervasive work in the area of professional responsibility. See e.g. Trevor C.W. Farrow, "Reviewing Globalization: Three Competing Stories, Two Emerging Themes, and How Law Schools Can and Must Participate" (2003) 13 Meikei L. Rev. 176 at 179, n. 66 and surrounding text, trans. into Japancse by M. Kuwahara, (2003) 44 Aichigakuin L. Rev, 29, republished (2004) 5 J. Centre for Int'l Siud. J, as influenced by Deborah L. Rhode, Professional Responsibility: Ethics By the Pervasive Method, 2d ed. (New York: Aspen Law \& Business, 1998).

* Although I approach this calaloguing exercise differently, I was influenced in my thinking in this area by ADR program review reports done at Saskatclicwan and Toronto. See "Saskatchewan Review Project," supra note 80; "How We Got to Yes," supra note 80. See also "CBA Survey," supra note 14 at 20-25; "The Significance of Mediation for Legal Education," supra note 80. One potentiaily useful approach that I did not ultimately follow - cataloguing the various Canadian programs in terms of clinical, non-clinical and integrated approaches - was raised as an alternative in an anonymous peer review of this article. 
and/or clinical offerings. Further, specific graduate work and professional development ${ }^{89}$ initiatives are also offered by several programs. ${ }^{90}$

\section{B. UNIVERSITY INSTITUTES TOGETHER WITH LAW FACULTY COURSES}

Three Canadian universities that currently have dispute resolution institutes and/or intensive programs complementing law faculty ADR course offerings include Victoria, UBC and Dalhousie."

\section{UNIVERSITY OF VICTORIA}

\section{a. Institute for Dispute Resolution (IDR) ${ }^{92}$}

Victoria's IDR has a broad, interdisciplinary and international focus for teaching, research, graduate study and professional development. According to its materials, the IDR "has conducted research and disseminated dispute resolution knowledge through local, national and international conferences and symposiums and professional development workshops." Further, it provides "professional education and training in dispute resolution for public and private sector organizations." Finally, its "focus on public policy issues led to the

ny There are numerous ADR professional development programs in Canada. In addition to the Universitybased programs catalogued in this article, there are numerous law society, regional legal education and $C B A$ programs available in the area of $A D R$ iraining. (ther programs also include, for example, the Justice Institute of B.C., Centre for Conflict Resolution (see online: <www.jibc.bc.ca/ccr/default.htm>); and the Alberta Arbitration and Mediation Society (see online: <www.aams.ab.ca/>), in collaboration with Grant MacEwan College (see online: <www.macewan.ca/web/ims/client/upload/Focus_on_Part time.pdf>.

*) For useful Canadian sources of dispute resolution links, see e.g. University of Victoria. Institute for Dispute Resolution, "Links," online: University of Victoria <http://dispute.resolution.uvic.ca/links. htm>, ADR Institutc of Canada, "News \& Information: Links," online: ADR Institutc of Canada <www.adrinstilute.ca/ news/links.html>.

4t Four further institutions could have been catalogued in this section. First, Osgoode Hall Law School could have been included logether with York University's LaMarsh Centre for Research on Violence and Conflict Resolution (see online: York University <ivww.yorku.ca/vpri/publichome/publications/ file_lamarsh-00-01,pdP). However, given the disconnect between the Osgoode and the LaMarsh Centre (see "ADR Survey," supra note 14), Osgoode's ADR program has been included in the course-based section (infra noles 150-55). Second, for similar reasons, the Universily of Toronto. Faculty of Law is included in the course-based section (infra notes 145-49), nolwithstanding the University of Toronto's Program on Conflict Management and Negotiation (see online: University of Toronto <www.utoronto.ca/pcmn>). Third, the University of Alberta, Faculty of Law is in the process of developing a research and teaching-based "Dispute Resolution Project." Once completed, it could be moved to this section from the course-based section (infra notes 124-28). Fourth, to the extent that the University of Windsor, Facully of Law's dispute resolution institute becomes an operational reality (sec infra note 141 and surrounding (ext), it could be moved to this section from the course based seclion as well.

92 See online: University of Victoria <uww.dispute.resolution.uvic.ca/mandate.htm>. See also the discussions of the IDR in "The Significance of Mediation for Legal Education," supra note 80 at 284. 85; Maureen Maloney, "Considering public policy dispute resolution" The Law)ers Weekly. (2! January 2005) 11 
development and implementation in 1998 of an interdisciplinary graduate program in public policy dispute resolution." 93

\section{b. Faculty of Law}

In addition to the numerous courses offered through the IDR, Victoria's Faculty of Law has integrated dispute resolution concepts into "many regular courses." 95 Further, Victoria lists five specific dispute resolution courses:

- Collective Agreements: Negotiation and Arbitration;

- Dispute Resolution: Theory and Practice;

- Legal Skills;

- Advocacy; and

- Public Policy, Law and Dispute Resolution. ${ }^{96}$

Victoria also offers, in conjunction with the IDR, an interdisciplinary graduate program? and professional development courses. ${ }^{98}$ Finally, through the IDR, Victoria identifies itself as having a leading interest in dispute resolution research. ${ }^{99}$

\section{UNIVERSITY OF BRITISH COLUMBIA}

\section{a. Program on Dispute Resolution (PDR) ${ }^{100}$}

The University of British Columbia's (UBC) PDR - a University-wide initiative involves a combination of teaching, research and public service. Further, the PDR provides professional development courses. ${ }^{101}$ UBC is also in the process of establishing the Nemetz International Centre for Conflict Resolution: an Asian-Pacific conflict resolution program housed at UBC that involves a number of international institutional partners and research initiatives. $^{102}$

Online: University of Vietoria <iwww. dispute.resolution.uvic.ca/history.htm>. According to its public materials, the IDR has one "faculty" member, three "teaching faculty" members (from other faculties at the University and elsewhere) and approximately cleven faculty "Associates" (ibid.). See online: University of Victoria, Faculty of Law < wnv.law.uvic.ca>. The Faculty of Law advertises one faculty member specifically interested in dispute resolution (ibid.). "How We Got to Yes," supra note 80 at 8. Supra note 94.

${ }^{77}$ Victoria offers an interdisciplinary M.A. in Dispute Resolution, including a thesis and non-thesis option. See online: University of Victoria <www.disputc.resolution.uvic.ca/madr/prog_req.htm>. The IDR also has faculty members, from various University of Victoria faculties, available "for thesis supervision" of graduate students. See online: University of Victoria < wnw.dispute.resolution. uvic.ca/people/supervision.htm>.

* Online: University of Victoria <www.dispute.resolution.uvic.ca/research/index.htm>.

Iti' Sec online: PDR < www.disputeresolution.ubc.ca/mission.htm>. See also the discussion of the PDR in "The Significance of Mediation for Legal Education," supra nole 80 at 285.86. 


\section{b. Faculty of Law ${ }^{103}$}

In addition to the courses offered through the PDR, the UBC Faculty of Law offers approximately 20 dispute resolution courses (including courses on ADR as well as traditional civil litigation and advocacy, etc.). ${ }^{10-1}$ In terms of specific ADR-related courses, UBC's offerings include:

- International Commercial Disputes;

- Resolution of Labour Disputes;

- Negotiation and Dispute Resolution;

- Alternative Dispute Resolution;

- Dispute Resolution Theory;

- Mediation Clinic;

- Topics in Litigation, Dispute Resolution and Administration of Justice (including topics in "mediation advocacy," "Aboriginal law litigation" and "intercultural dispute resolution"); and

- A graduate seminar in Cross-Cultural Conflict Resolution in the Asia Pacific. ${ }^{105}$

UBC also offers students an ADR stream, ${ }^{106}$ clinic-based offerings through the UBC Conflict Resolution ("CoRe") Program, ${ }^{107}$ and — in partnership with UBC's PDR — an interdisciplinary graduate program. ${ }^{108}$

See online: UBC, Faculty of Law < $4 m w$.law.ubc.ca/current/lb/curriculum/>. See also "ADR Survey," supra note 14. The UBC Faculty of Law, according to the "ADR Survey," has two full-time faculty members specifically interested in dispute resolution. It also has 6-8 part-time/sessional instructors.

lbid.

Ibid. See also "ADR Survey," supra note 14.

Three-year theoretical and skills-based curriculum.

This program is described as a

[n]onprofit mediation service run by student volunteers who have trained with the UBC Faculty of Law Program on Dispute Resolution. The mediator facilitates communication to help the people with the dispute reach a mutually agreeable resolution; they do not give legal advice or impose decisions. The process is suitable for disputes such as neighbour, community/campus, employment, housing/roommate, small claims, debt collection, and division of propenty. Mediation costs $\$ 25$ per party, are voluntary, and are confidential and without prejudice for any future court actions" ("CoRe (Conflict Resolution) Clinic," online: Vancouver Public Library <www2.vpl.vancouver.bc.ca/dbs/redbook/orgpgs/l//0884.html>).

Further, as described on its web materials, UBC offers a "Clinical Term" in which students: (a) have classroom work; and (b) work for three days a week at the UBC First Nations Legal Clinic. In addition. UBC also offers a "Mediation Clinic," which includes co-mediation at the Small Claims Court.

Supervision is available for M.A. and Ph.D. students - enrolled in the Faculty of Law or other faculties - from the PDR. See online: PDR <www.disputeresolution.ubc.ca/mission.htm>. UBC is also looking to expand further its graduate program to include a comprehensive LL.M.M.A. degree and an interdisciplinary Ph.D. program: "ADR Survey," supra note I4. 


\section{DALHOUSIE UNIVERSITY}

a. Negotiation and Conflict Management Programme (NCMP)

Dalhousie University - through Dalhousie Law School, Henson College of Public Affairs and Continuing Education, and laterally with the Maritime School of Social Work - offers the NCMP. Its mission is to "improve the quality of public, private and community decision making and conflict management by providing individuals and organizations with the most innovative training in negotiation and mediation available." ${ }^{10} \mathrm{NCMP}$ participants can receive a Certificate in Dispute Resolution, involving both a written component as well as a practical component. Specialized, topical workshops are also offered from time to time. ${ }^{\prime \prime \prime}$

b. Faculty of Law ${ }^{112}$

Dalhousie lists two specific ADR-related courses, including:

- Dispute Resolution Processes; and

- Family Law Dispute Resolution. ${ }^{113}$

\section{INTEgRATED - "PERVASIVE" — APPROACHES TO ADR}

Two Canadian law schools teach ADR primarily through an integrated — "pervasive" approach in their first year programs, followed by further ADR courses offered at the upper year levels. These schools are Saskatchewan and Ottawa.

\section{University of SASkatchewan, College of LaW 114}

Saskatchewan introduces its students to dispute resolution, through a "pervasive" method, in each of its first year core courses. This program, which is in turn influenced significantly

wy See online: Dalhousie University <www.dal.ca/-henson/ncmp/ncmp.html>. For a recent discussion of the NCMP, see "The Negotiation and Conflict Management Programme Continues to Thrive" Hearsay: Dalhousie Lav School Alumni Magazine 27:I (2003) 42 ["The Negotiation and Conflict Management Programme Continues to Thrive"].

110 See online: Dalhousie University <wrww.dal.ca/-henson/ncmp/ncmp.html>.

III "The Negotiation and Conflict Management Programme Continues to Thrive," supra note 109.

112 See online: Dalhousie University, Faculty of Law <http:/law.dal.ca/indix.htm $>$. Dalhousie Law School specifically identifies two faculty members teaching in the area of dispute resolution. See further the discussion of Dalhousie's program in "The Significance of Mediation for Legal Education," supra note 80 at 290.

11! Online: Dalhousie University, Faculty of Law <http://aw.dal.ca/law_2475.html>.

IIt See online: University of Saskatchewan, College of Law <www.usask.ca/law/>. Further information concerning the Saskatchewan program and its development came from a 12 December 2003 telephone conversation with Michaela Keet, University of Saskatchewan, College of Law ["Keet Conversation"]. See also "Saskatchewan Review Project," supra note 80; "The Significance of Mediation for Legal Education," supra note 80 at 286-87. 
by the pervasive-method program at the University of Missouri-Columbia, School of Law, ${ }^{1 / 5}$ is described as the first year "Dispute Resolution Program."

In addition to the first year program, Saskatchewan also has a number of upper year elective courses, described as a "focus area" on dispute resolution. 116 Saskatchewan's ADRrelated course offerings include:

- Alternative Dispute Resolution;

- Mediation (with a clinical component);

- Labour Law;

- Labour Arbitration;

- Multi-Party Institutional Conflict Resolution;

- Intense Dispute Resolution Course - "Independent Clinical Experience" — with a current focus on dispute resolution (in either a mediation or restorative justice stream); and

- Conflict Resolution Theory (not offered every year). ${ }^{117}$

\section{UNIVERSITY OF OTTAWA, FACULTY OF LAW ${ }^{\prime \prime B}$}

Until recently, ADR was taught in the first year Contracts and Property courses. ${ }^{119}$ Now, as a preliminary matter, ADR is a compulsory first year course. It is taught in two components. First, six hours of classes and exercises are offered in the first term. Then, ADR is taught in a three-week intensive winter term format. The course draws on substantive law courses - Contracts, Torts, Property, etc. - in order to introduce approaches to dispute resolution through a contextual format. ${ }^{120}$

Following the first year program, Ottawa has several upper year dispute resolution requirements (including civil procedure and advocacy). The flexible advocacy component

Discussed further, infra notes 203-13. The person primarily responsible for the success of the Missouri model is Professor Leonard L. Riskin. See online: University of Missouri-Columbia, School of Law <www.law.missouri.edu/faculty/faculty/riskin.htm>.

From 23 February 2005 telephone conversation with Michacle Keet. University of Saskatchewan, College of Law.

University of Saskatchewan, College of Law public material [archived with author] and from 2 October 2004 email correspondence with Michaela Keet, University of Saskatchewan, College of Law. Saskatchewan has three faculty members interested in dispute resolution, together with several sessional instructors teaching in the area. See "Saskatchewan Review Project," supra note 80. Saskatchewan also has other courses that include some aspect of dispute resolution theory or practice, including family law. aboriginal law and civil procedure.

See online: University of Ottawa, Faculty of Law <www.commonlaw.uottawa.ca/eng/academic/ programs $/$ lb.htm $>$. Ottawa has 2-3 faculty members specifically interested in dispute resolution. It also has 4-5 ADR sessional instructors. See "ADR Survey," supra note 14. For useful discussions of Ottawa's program in the context of ADR curriculum reform, see Ellen Zweibel, "Where Does ADR Fit in the Mainstream Law School Curriculum" (1999) 17 Windsor Y.B. Access Just. 295; "The Significance of Mediation for Legal Education," supra note 80 at 288.89. Sec also the complementary comments made by the Australian Law Reform Commission: "ALRC Discussion Paper," supra note 44 at para. 3.43. 
can be fulfilled by taking several ADR-related (or other) course offerings, which also can be taken as additional, optional courses. The specific ADR-related courses include:

- Altemative Dispute Resolution Processes;

- ADR Practicum;

- Mediation Theory and Practice;

- Mediation Involving Families;

- Advanced Business Law;

- Interviewing, Counseling and Negotiation;

- Labour Law II; and

- Family Conflicts Resolution. 21

In addition to these law school ADR programs, the ADR instructors at Ottawa supervise "some" individual ADR graduate students. ${ }^{122}$ They also offer ADR courses at Ottawa's Faculty of Medicine. ${ }^{123}$

\section{D. “Traditional" Course-Based ADR Programs}

The remainder of the common law programs in Canada offer ADR through various forms of the traditional course-based method.

\section{UNIVERSITY OF ALBERTA, FACULTY OF LAW ${ }^{124}$}

Currently, ADR at the University of Alberta, Faculty of Law is taught primarily through the following three courses:

- Alternative Dispute Resolution; ;2s $^{2}$

- Techniques in Negotiation; and

- Labour Arbitration. ${ }^{126}$

Further, Alberta offers several other courses with ADR-related components, including:

- Interviewing and Counselling;

- International Business Transactions;

- Labour Law;

- Advanced Labour Law;

- Civil Procedure;

Online: University of Ottawa, Facully of Law <www.commonlaw.uottawa.ca/eng/academic/ programs/llb.htm>. Sce also "ADR Survey," ibid.

"ADR Survey," ibid.

Ibid.

Sce online: University of Alberta, Faculty of Law <www.law.ualberta.ca>. See further the discussion of Alberta"s program in "The Significance of Mediation for Legal Education," supra note 80 at 286. For an example of the approach taken in this basic ADR course, see Trevor C.W. Farrow, "Alternative Dispute Resolution" (course outline, 2004), online: University of Alberta, Faculty of Law <innw.law. ualberta.ca/courses/farrow/adr/index.hım>. Online: University of Alberta, Faculty of Law < wnw.law.ualberta.ca>. These courses are taught by Iwo
full-time faculty members as well as by several sessional instructors. 
- Family Law;

- Aboriginal Peoples and Law;

- Jurisprudence: The Emotions of Conflict and Justice; and

- Professional Responsibility. ${ }^{127}$

Finally, Alberta has graduate work being done in the area of ADR. In addition to its current offerings, however, Alberta is in the process of developing a wide-ranging research and teaching-based "Dispute Resolution Project."128

\section{University OF CALGARY, FACUITTY OF LAW ${ }^{129}$}

Calgary's ADR course offerings include: ${ }^{130}$

- Interviewing, Negotiation and Counselling;

- Dispute Resolution; and

- Advanced Labour Law (labour arbitration course). ${ }^{131}$

There are also elements of ADR in the following course offerings:

- Civil Evidence and Procedure;

- Advanced Environmental Law; and

- Family Clinical Seminar. ${ }^{132}$

The only graduate ADR work being done at Calgary is "incidental" to its main areas of graduate focus. ${ }^{133}$ Outside of the Faculty of Law, the University of Calgary also offers, through a partnership between the Faculty of Continuing Education and the Alberta Arbitration and Mediation Society, continuing education courses in conflict resolution. ${ }^{14}$ Over the next several years, Calgary may seek to develop its ADR offerings, particularly as

Jbid. The amount of ADR-related material that is covered in these various courses depends entirely on the interest and expertise of the instructor. For examples of ADR coverage in these related courses, sec e.g. Trevor C.W. Farrow, "Civil Procedure" (course oulline, 2003-2004), online: Universily of Alberta. Faculty of Law <unw law.ualberta ca/courses/farrow/civ_pro/index.htm>; Trevor CW. Farrow, "Professional Responsibility" (course outline. 2003), online: University of Alherta, Faculty of Law <wiw.law.ualberta.ca/courses/farrow/prof_resp/index.lutm>. Other ADR-related initiatives at the Faculty of Law include: (a) four ADR-related moots (the Client Counselting Competition, the Kawaskimhon National Aboriginal Moot. the Labour Arbitration Moot Competition and the Fraser. Milner, Casgrain Negotiation Competition); (b) the work being done by the CFCJ (set unline: CFCJ <www.cfcj-fcjc.org/index.htm>); and (c) Alberta's Student Arbitration \& Mediation Socicty. As mentioned above, supra note 91 .

129 See online: University of Calgary, Faculty of Law <iwww,law, ucalgary.ca>. See also "ADR Survey," supra note 14.

(*) For an earlier description of Calgary's offerings, sec "The Significance of Mediation for Legal Education," supra nole 80 at 281-84. See also online: University of Calgary, Faculty of Law <iwww.law. ucalgary.ca/correct_students/course_descriptions.hımi>.

ii' $\quad$ bid.

11: lbid. Calgary typically has 1-2 full-time facully members fully or partially focusing on ADR. In addition, it has 1 full-time insiructor teaching its compulsory interviewing course.

in $\quad$ bid.

iu Online: University of Calgary < www.ucalgary.ca/UofC/faculties/CTFD/certificales.html> See alsu "ADR Survey;" supra note 14. 
they relate to the larger research and teaching initiatives that are part of Calgary's upcoming five-year strategic plan of expansion and renewal entitled "Fostering Excellence: Seizing the Initiative."135

\section{UNIVERSITY OF MANITOBA, FACULTY OF LAW'136}

Manitoba offers 13 dispute resolution-related courses (including offerings in civil procedure, professional responsibility, elc.). In terms of specific ADR courses, Manitoba's offerings include:

- Legal Negotiation (mandatory second year course);

- Dispute Resolution: Theory and Practice; and

- Labour-Management Relations. ${ }^{137}$

Manitoba does not have any ADR graduate work being done, nor does it offer any ADR professional development courses.

\section{UNIVERSITY OF WINDSOR, FACULTY OF LAW'138}

Windsor has a number of ADR initiatives. In terms of course offerings, Windsor advertises several ADR-related courses, including:

- Access to Justice: Dispute Resolution;

- Labour Arbitration;

- The Lawyering Process: Interviewing, Counseling and Negotiation; and

- The Mediation Clinic.

Windsor also offers, in conjunction with its Mediation Clinic course, community mediation services through its University of Windsor Mediation Service (UWMS): a "free University and community service" offered for legal disputes before or after a law suit is commenced. It also mediates non-legal disputes. The services are provided by law students. ${ }^{139}$

Online: University of Calgary, Faculty of Law <www.law.ucalgary.ca/Developmentstrategic_plan.pdßs. According to the "ADR Survey," Calgary is "near the beginning of a total curriculum review." Options that have been discussed include revising and adding ADR courses and/or making ADR part of the required first year program: "ADR Survey," ibid. Online: University of Manitoba, Faculty of Law <www.umanitoba.ca/faculties/law/newsite/index.php>. Ibid. Manitoba is also considering developing an ADR clinic. While the Faculty of Law has two faculty members interested in dispute resolution, it does not list any "full-time" ADR instructors. It typically has 2-3 sessional ADR instructors. Sec further the discussion of Manitoba's program in "The Significance of Mediation for Legal Education," supra nole 80 at 287.

See online: University of Windsor, Faculty of Law <http://athena.uwindsor.ca/law>. Windsor's Faculty of Law lists three faculty members specifically interested in dispute resolution. Ibid. Sce further the discussion of Windsor's program in "The Significance of Mediation for Legal Education," supra note 80 at $290-91$. 
Further, Windsor offers an innovative internship program, the Osler Hoskin Harcourt Internships in Law Program, which began in 1999.140 Finally, Windsor has been experimenting with the development of the Dispute Resolution Institute of North America (DRINA). ${ }^{141}$

\section{UNIVERSITY OF WESTERN ONTARIO (UWO), FACULTY OF LAW ${ }^{142}$}

Western offers approximately eight dispute resolution-related courses (including offerings in civil procedure, evidence and advocacy, etc.). In terms of specific ADR courses, UWO's offerings include:

- Labour Arbitration Competition;

- Dispute Settlement;

- Negotiation and Mediation; and

- Arbitration Law and Procedure.

In addition to these courses, Western offers a significant ADR-related clinical program: the Dispute Resolution Centre. ${ }^{143}$ The Dispute Resolution Centre is a "not-for-profit organization," operated "by law students under the supervision [of] the Faculty" that "provides mediation services" to local residents. ${ }^{144}$

\section{UNIVERSITY OF TORONTO, FACULTY OF LAW ${ }^{145}$}

According to its publicly available materials, Toronto lists a number of ADR-related courses, including:

- Alternative Dispute Resolution;

- Advanced Alternative Dispute Resolution;

- Negotiation;

According to Windsor's public materials:

Internships are offered as a supervised rescarch program for upper-year law students who have some prior experience or training in mediation skills. Most internships involve work in the UWMS office, conducting outreacli, case intake and development, and co-mediating cases with the Director. Some internships involve external placements with local organizations or businesses.

See Univeristy of Windsor, Faculty of Law, Prospectus 2004-2006 (Windsor: Public Affairs \& Communications, University of Windsor, 2003) at 22, online: University of Windsor <hitp://athena.uwindsor.ca/units/law/Law.ns//eb89096e0dace88785256921004529d8/12de5cfe8b 25bla285256921004ee3e5/SFILE/Prospectus\%20-\%202004-06.pdß.

For an early description of DRINA, see a previous welcome message from Windsor's dean, [unpublished, archived with author]. It appears, however, that this initiative is not being actively carried forward at this time. 1 am grateful to anonymous peer review comments regarding the current status of DRINA.

See online: UWO, Faculty of Law <www.law.uwo.ca>. The Faculty of Law identifies two faculty members specifically interested in dispute resolution. See further the discussion of Western's program in "The Significance of Mediation for Legal Education." supra note 80 at 290. See online: UWO <hutp://clubs.law.uwo.ca/dre/s.

14 Ibid.

14s See online: University of Toronto, Faculty of Law <www.law.utoronto.ca>. For helpful background information, see also "How We Got to Yes," supra note 80. See further the discussion of Toronto's program in "The Significance of Mediation for Legal Education," supra note 80 at 287-88. 
- Theory of Negotiation;

- Labour Arbitration; and

- Dispute Settlement in International Trade: Law, Policy and Procedure in the WTO and NAFTA. ${ }^{146}$

ADR is also taught - in an introductory fashion - during Toronto's first year Legal Process course. ${ }^{147}$ Toronto lists no full-time faculty member specifically interested in ADR. It does, however, have indirect access to Toronto's Program on Conflict Management and Negotiation (PCMN). ${ }^{148}$ In addition, Toronto also offers courses in professional development. ${ }^{149}$

\section{OSGOODE HALL LAW SCHOOL (YORK UNIVERSITY) ${ }^{150}$}

In Osgoode's first year program, students are introduced to ADR in a traditional civil procedure course. ${ }^{131}$ Further, students choose a "perspectives option," one of which includes "Dispute Settlement." In the upper years, Osgoode offers students the opportunity to do course work as part of specific curricular "streams." ADR-related courses - as part of the "Litigation, Dispute Resolution and the Administration of Justice" curricular stream ${ }^{152}$ include:

- International Dispute Resolution;

- Lawyer as Negotiator (upper year elective);

- Dispute Settlement;

- Litigation, Dispute Resolution and the Administration of Justice Colloquium; and

- Theory and Practice of Mediation. ${ }^{133}$

1st Online: University of Toronto, Faculty of Law <ww.law.utoronto.ca>.

147 See e.g. Trevor C.W. Farrow, Legal Process (II), in University of Toronto, Faculty of Law, "First Year Syllabus and Academic Handbook, 2004-2005" at 8, online: <www.law.utoronto.ca/documents/ JD/syl04_firstyear.pds.

148 Ontine: University of Toronto <www.utoronto.ca/pcmn/menu.html>. According to Toronto's public materials, PCMN "is designed to meet the local, national and international need for rescarch, education and training in negotiation, conflict management and dispute resolution." It is located in Toronto's Munk Centre for International Studies. In addition to several full-time faculty members, PCMN includes a "faculty group of more than 20 distinguished practitioners." PCMN, which offers a Certificate in Continuing Studies in Dispute Resolution, is "not affiliated with the law school" ("How Wc Got to Yes." supra note 80 at 8 ).

Toronto - through its School of Continuing Studies and PCMN - offers a professional development certificate in dispute resolution. See online: University of Toronto <http://learn.utoronto.ca/uoft professional/certificatesDisputeResolution.jsp $>$. It also offiers further dispute resolution courses through its School of Continuing Studies. See online: University of Toronto <http///earn.utoronto.ca/ uof/public ViewHome.do?method=load?.

See online: Osgoode Hall <www.osgoode. yorku.ca/>. See also "ADR Survey," supra note 14. Osgoode lists 5.6 faculty members interested in disputc resolution and relaled topics. Two of these faculty members specifically leach ADR. Further, Osgoode las "numerous" adjunct professors/sessional instructors teaching dispute resolution. See also the discussion of Osgoode's program in "The Significance of Mediation for Legal Education," supra nole 80 at 288.

Is1 See e.g. Osgoode Hall Law Sclıool, "First Year Description" (Civil Procedure), online: Osgoode Hall <www.osgoode.yorku.ca/firstyearprog.htm>.

is: Online: Osgoode Hall <iwww.osgoode. yorku.ca/>.

15. Students also have an oppontunity to attend mediations at the local small claims court. "ADR Survey," supra note 14. 
In terms of graduate programs, Osgoode has two "part-time" LL.M. programs in dispute resolution, "specializing" in ADR and Civil Litigation and Dispute Settlement. ${ }^{154}$ Finally, in addition to its part-time LL.M. programs, Osgoode also offers - through its "continuing legal education" program — ADR "workshops and courses."15s

Outside of the Faculty of Law, dispute resolution certificates are available through a program co-sponsored with York University's Atkinson Faculty of Liberal and Professional Studies, the School of Social Work and the LaMarsh Centre for Research on Violence and Conflict Resolution. ${ }^{156}$

\section{QUEEN'S UNIVERSITY, FACULTY OF LAW'157}

Queen's offers eight dispute resolution-related courses (including offerings in civil procedure, advocacy, etc.). In terms of specific ADR-related courses, Queen's offerings include:

- Advanced Civil Procedure;

- Alternative Dispute Resolution;

- Client Counseling and Dispute Resolution;

- Industrial Dispute Resolution; and

- Negotiation. . $^{158}$

\section{MCGILL UNIVERSITY, FACULTY OF LAW 159}

McGill offers several ADR-related courses, specifically including:

- Comparative Legal Institutions;

- Resolution of International Disputes; and

- Dispute Resolution. ${ }^{160}$

In addition to its regular degree, McGill also offers students the opportunity to specialize in various focus areas: the "advanced law" programs. These programs include the "minors,"

Part of Osgoode's ADR I.I.M. program includes a full semester practicum in the second year, during which students spend at least 100 hours involved in "dispute resolution design, teaching or practice" (ibid.). See also online: Osgoode Hall <iwww.law.yorku.ca/pdp/llm/lmmain.hım>.

This is an extensive program that developed out of Osgoode's part-time LL.M. program. The courses are offered in downtown Toronto office space. See "ADR Survey," supra note 14. See also online: Osgoode Hall <www.law.yorku.ca/pdp/cle/default.htm>.

Online: York University <www. atkinson.yorku.ca/ -dce/Programs/Certificates/Certificates.html>. See also online: York University <www.yorku.ca/vpri/publichome/publications/file_lamarsh-00.01.pd\$ . For a brief discussion concerning the relationship between Osgoode and these wider York University programs, sce supra note 91 .

See online: Queen's Universily, Faculty of Law <littp://law.queensu.ca/index.php>. The Faculty or Law lists no full-time faculty member specifically interested in ADR (although some dispute resolution issues are taught by a full-time faculty member in the labour law context).

Ibid. See further the discussion of Queen's program in "The Significance of Mediation for Legal Education," supra note 80 at $289-90$.

See online: McGill University, Faculty of Law <www.law.mcgill.ca/>.

lbid. McGill lists one faculty member specifically interested in dispute resolution issues. 
"majors" and "honours speciality" programs. They are optional programs - requiring an extra, fourth year - leading to the same BCL/LL.B. degree. They all involve taking between 15-18 credits over and above the regular required 105 credits. The majors program includes concentration options in Commercial Negotiation and Dispute Resolution. ${ }^{161}$

10. UNIVERSITY OF NEW BRUNSWICK (UNB), FACULTY OF LAW 162

UNB lists two ADR-related course offerings, including:

- Collective Bargaining and Arbitration; and

- Dispute Resolution. ${ }^{163}$

\section{E. UNiversities With Other LaW Programs}

Materials for two universities with programs in law-related fields were specifically reviewed in the context of this article: Carleton and Royal Roads.

\section{Carleton University, Department of LaW ${ }^{16+}$}

Carleton (through the Department of Law and other units) offers B.A. degrees in Law, Criminology, Criminal Justice and Human Rights, an M.A. in Legal Studies and a Graduate Certificate in Conflict Resolution. ${ }^{165}$

Carleton also offers - through the Carleton University Mediation Centre - assistance to "individuals and groups in conflict at the University." Students, staff and faculty "can access the Centre for free." Volunteers for the Centre - from "faculty, staff, students and Ottawa South residents" - are trained by the Centre as mediators and "supervised by Centre staff." 160

\section{ROYAL ROADS UNIVERSITY ${ }^{167}$}

Royal Roads has developed a significant reputation for conflict resolution teaching and research. According to its public materials, Royal Roads provides ADR training as part of its B.A. in Justice Studies. Further, it also has M.A. programs in Conflict Analysis and Management, and Human Security and Peacebuilding. ${ }^{168}$

Ibid.

See online: UNB, Faculty of Law <www.law.unb.ca>.

lbid. The Faculty lists one member interested in dispute resolution. See further the discussion of UNB's program in "The Significance of Mediation for Legal Education," supra note 80 at 290. See online: Carleton University <www.carleton.ca/law>.

Ibid.

Online: Carleton University <www.carleton.ca/equity/Mediation_Centre/mediation_centre.html>.

See online: Royal Roads University <www.royalroads.ca>. 


\section{FOREIGN DISPUTE RESOLUTION PROGRAMS}

\section{A. BACKGROUND}

This part of the article catalogues a selection of various dispute resolution approaches of leading international institutions and ADR programs. Given its range and the programs discussed, it purports to provide a good sense of the various ways that different common law jurisdictions are approaching dispute resolution teaching and research around the world. ${ }^{169}$

\section{B. UNITED STATES}

Because Canada has tended to follow the American lead in terms of teaching and research in $\mathrm{ADR},{ }^{170}$ the various American programs catalogued in this section provide a useful guide for future thinking and initiatives in Canada. ${ }^{17}$

1. HaRVARd LaW School ${ }^{172}$

a. Courses

Harvard has a long tradition and wide range of course offerings in the area of dispute resolution, including:

- Alternative Dispute Resolution: Overview;

- Alternative Methods of Dispute Resolution: Reading Group;

- Interdisciplinary Approaches to Dispute Resolution;

- Arbitration, Mediation and Dispute Resolution Design;

- Mediation;

- Mediation: Dealing with Emotions;

- Negotiation and Dispute Resolution: Interdisciplinary Research;

- Negotiation Workshop (an intense, 3-week winter term course); and

For a very useful source of United Stales academic programs, see "Twenty-Five Years Later with Promises to Keep," supra note 23 at 598-601. For useful online sources of international ADR programs. links, etc., see e.g. Deborah S. Laufer, "A Guide to ADR Links," online: Air Force ADR Program $<w w w . a d r . a f . m i l / g e n e r a l / g u i d e a d r$ doc>; University of Missouri-Columbia, School of Law, ontine: University of Missouri-Columbia <www.law.missouri.edu/csdr/adr.htm>; New Zealand Centre for Conflict Resolution (NZCCR), "Links," online: NZCCR <www.lawschool.vuw.ac.nz/vuw/contenU display_content.cfm?school=law\&id $=480 \mathrm{H} 4$.

See e.g. "Thinking About Dispute Resolution," supra note 7 at 563 . See also Readings and Case Studies, supra note 7 at xvii.

For further selected American programs and initiatives, see Case Western Reserve University, Center for the Interdisciplinary Study of Conflict and Dispute Resolution, Press Release, "Case School of Law creates center for interdisciplinary study of conflict, dispute resolution" (9 July 2004), online: Case $<w w w . c a s e . e d w / n e w s / 2004 / 7-04 /$ conflictetr.htm>; DePaul University, Center for Dispute Resolution, online: DePaul University <https://learning.depaul.edu/about/centers/disputc.asp>: University of Massachusetts Amherst, The Center for Information Technology and Dispute Resolution (CITDR). online: CITDR < www.odr.info/index.php>: Willamette College of Law. Center for Dispute Resolution, online: Willamette College of Law <www.willamette.edu/wucl/cdr>. 
- Negotiation Workshop Advanced: Multi-party Negotiation. ${ }^{13}$

Other courses, while not specifically focused on ADR, include an ADR component, including, for example:

- Labor Law; and

- Environmental Law. ${ }^{174}$

In addition, Harvard has a number of graduate students working in the ADR area. They also have the opportunity to cross-register in courses elsewhere at Harvard University ${ }^{175}$ as well as at MIT ${ }^{176}$ and the Fletcher School ${ }^{177}$ at Tufts University. ${ }^{178}$ Further, Harvard is able to offer ADR-related funding, through its Program on Negotiation Graduate Research Fellowships. ${ }^{179}$

b. Dispute Resolution Programs and Projects

Harvard has an extensive series of ADR programs and projects that focus on various aspects of teaching, research, policy and professional development. These initiatives include the:

- Program on Negotiation; ${ }^{180}$

- Harvard Negotiation Project;

- Harvard Mediation Program; ${ }^{181}$

- Harvard Negotiation Research Project; and

- Project on International Institutions and Conflict Management. ${ }^{182}$

c. Journals

Harvard has two primary ADR joumals:

- Harvard Negotiation Law Review; ${ }^{183}$ and

Ibid. Sce also "ADR Survey," supra note 14. Harvard has 3-4 faculty members/lecturers researching and/or teaching in the area of dispute resolution. It also has 6-7 part-lime/sessional ADR instructors. See "ADR Survey," ibid.

Online: Harvard University <wmw.harvard.edu/s.

See online: MIT <http://web.mit.edu>>.

See online: Fletcher School <hitp://fletcher.tufts. edu/s.

See online: Tufts Unviersity <www.tufts.edu> $>$. See "ADR Survey," supra note 14.

Online: Program on Negotitation <www.pon.harvard.edu/education/fellowship/index.php3>.

This Program is an "inter-university consortium committed to improving the theory and practice of negotiation and dispute resolution." Online: Program on Negotiation <www.pon.harvard.edu/main/ home/index.php3>. It also offers a once-a-week seminar in negotiation and third party processes; "ADR Survey," supra notc 14.

This is a student-run program that trains students in mediation and then placts them in the small claims court: "ADR Survey," ibid.

These programs - together - are primarily designed for research and continuing/professional legal education purposes.

Online: Program on Negotiation <www.pon.harvard.edu/publications/hnlr/index.php3>. This is a student run journal. See “ADR Survey,” supra note 14. 
- Negotiation Journal on the Process of Dispute Seltlement. ${ }^{184}$

\section{NEW YORK UNIVERSITY (NYU) SCHOOL OF LAW ${ }^{185}$}

New York University has a required first year lawyering course that looks, in the second term, at a number of issues related to negotiation and dispute resolution. In the upper years, NYU offers several ADR-related courses, including:

- Alternative Dispute Resolution;

- Negotiation; and

- Negotiation and Mediation Workshop. ${ }^{186}$

\section{UNIVERSITY OF CHICAGO LAW SCHOOL ${ }^{187}$}

Chicago offers several ADR-related courses in the upper years of the basic law degree, including:

- International Arbitration;

- International Dispute Resolution;

- Issues in Public Sector Labor Relations;

- The Lawyer as Negotiator; and

- Alternative Dispute Resolution. ${ }^{183}$

4. STANFORd LAW SCHOOL ${ }^{189}$

a. Courses

Stanford offers a wide range of ADR-related courses, including:

- Advanced Negotiation;

- Alternative Dispute Resolution;

- Conflict Resolution System Design;

- Interdisciplinary Seminar in Conflict and Negotiation;

- International Conflict;

- Interviewing, Counseling and Mediation;

- Mediation;

- Multi-Party Negotiations;

- Negotiation; and

- Problem Solving, Decision-Making and Professional Judgment. ${ }^{190}$

\footnotetext{
1s4 Online: Program on Negotiation <www.pon.harvard.edu/publicalions/nj/index.plip3>.

i*s See online: NYU Law < mww.law.nyu.edu>.

in. Ibid.

In] Sec online: University of Chicago Law School <www.law.uchicago.edu>.

1 Ibid.

18y See online: Stanford Law School <www.law.stanford.edu> 
These ADR courses are grouped together as "Dispute Resolution, Mediation and Negotiation" courses. ${ }^{191}$

b. Fellowships, Grants and Awards

Stanford has a significant array of ADR-related fellowships, grants and awards, including:

- Stanford Law School, Class of 2002 Fellowship in Conflict Resolution; ${ }^{192}$

- Stanford Center for Conflict and Negotiation, Graduate Fellowship Program; ${ }^{193}$

- Stanford Center for Conflict and Negotiation, Graduate Research Grant Program; and

- Stanford Center for Conflict and Negotiation, Richard S. Goldsmith Award. ${ }^{194}$

c. Centres and Programs

In addition to its course offerings, Stanford has three centres and ADR programs, including the:

- Martin Daniel Gould Center for Conflict Resolution; ${ }^{195}$

- Negotiation and Mediation Teaching Program; ${ }^{1 \%}$ and

- Stanford Center for Conflict and Negotiation. ${ }^{107}$

\section{UNIVERSITY OF CALIFORNIA AT BERKELEY, BOALT HALL SCHOOL OF LAW ${ }^{198}$}

Berkeley offers several ADR-related courses in its "Litigation and Procedure" cluster of courses, including:

- Mediation;

- Negotiations; and

- Resolution of Private International Disputes. ${ }^{199}$

191 These courses are listed separately from courses grouped as "Civil Procedurc and Litigation" courses (tbid.). Stanford also lists $\mathbf{4}$ faculty members researching and teaching in the dispute resolution area. Online: Stanford Law School <inww.law.stanford.edu/programs/academic/gould/nmtp/fellowship. htmls.

193 Online: Stanford Center on Conflict and Negotiation <iwww.stanford.edu/group/scen>.

im Jbid. This award is given for the "best paper on conflict resolution by a Stanford University student."

lys Online: Stanford Law School <www.lawschool.stanford.edu/programs/academic/gould/>. The Gould Center houses most classrooms and meeting spaces used for dispute resolution at Stanford. It also houses two other Stanford dispute resolution programs: the Negotiation and Mediation Teaching Program and the Stanford Center for Conflict and Negotiation.

1\%. Online: Stanford Law School <www.law.stanford. edu/programs/academic/gould/nmip/>. This program is designed to improve, increuse and coordinate the dispute resolution offerings in Stanford's law curriculum.

197 Online: Stanford Center for Conflict and Negotiation <www.stanford.edu/group/scen>. This is a University-wide "interdisciplinary center for the study of conflict and its resolution" (ibid.). It also has a significant graduate rescarch component.

1\%\% See online: Unjversity of California, Berkeley <www.law.berkeley.edu>.

194 lbid 
Berkeley also offers specific "curricular programs" that allow students to "focus their studies in a particular interest area and begin developing a specialty within the law."200 Included in these programs is the Professional Lawyering Skills Program. ${ }^{201}$ The Professional Lawyering Skills Program, in turn, includes skills development in traditional litigation techniques as well as "alternative dispute resolution, with a focus on negotiation and mediation."202

\section{UNIVERSITY OF MISSOURI-COLUMBIA, SCHOOL OF LAW ${ }^{203}$}

The University of Missouri-Columbia (UMC) is widely considered to be a leader in ADR teaching and research. The UMC School of Law has been ranked first among all U.S. law schools in dispute resolution by U.S. News and World Report since 1999, with more full-time faculty specializing in the area than any other law school. ${ }^{204}$

\section{a. Courses}

As a general matter, ADR is taught at UMC in both the first year and in upper year course offerings. The approach is largely through the pervasive method. ${ }^{205}$ In the first year, students are required to take the "Lawyering" course. This course is designed: to "provide students [with] an introduction to critical lawyering skills (e.g. interviewing, counsel[l]ing and negotiating) that all lawyers need regardless of their practice area"; to "give students an overview of the alternative processes that a lawyer can employ to resolve a client's problem"; and to "offer students a better understanding of the lawyer's role as a problem solver. This understanding will help ... put into context ... their substantive law courses. At the same time, however, [students] will gain an appreciation for the fact that clients' problems generally do not come in neatly defined substantive law packages."206

2(in) Online: University of California, Berkeley <www.law.berkeley. edu/cenpro/curricular.html>.

201 Online: University of California, Berkeley <mww.law.berkeley,edu/cenpro/clinical/proskills.html>.

2tr2 Hid.

301 See online: University of Missouri-Columbia, School of Law <www.law.missouri.edu/>.

its University of Missouri-Columbia, "Certificale in Dispute Resolution," online: University of MissouriColumbia, School of Law <www.law.missouri.edu/prospective/ADR.pdis. Elsewhere it has been similarly described as a "prominent example" of U.S. law schools that "focus on Alternative Dispule Resolution," particularly in the first year. "The MacCrate Report Turns 10," supra note 34 at I56. See generally Leonard L. Riskin \& James E. Westbrook, "Integrating Dispule Resolution into Standard First-Year Courses: The Missouri Plan" (1989) 39 J. Legal Educ. 509; Leonard L. Riskin, "Disseminating the Missouri Plan to Integrate Dispute Resolution into Standard Law School Courses: A Report on a Collaboration with Six Law Schools" (1998) 50 Fla. L. Rev. 589 ["A Report on a Collaboration with Six Law Schools"]; Ronald M. Pipkin, "Teaching Dispule Resolution in the First Year of Law School: An Evaluation of the Program at the University of Missouri-Columbia" (1998) 50 Fla. L. Rev. 609 ["Teaching Dispute Resolution in the First Year of Law School"]: Katheryn M. Dutenhaver, "Dispute Resolution and lis Purpose in the Curriculum of DePaul University College of Law" (1998) 50 Fla. L. Rev. 719 ("Dispute Resolution and Its Purpose"|: Lconard L. Riskin, "A Response to Professor Pipkin" (1998) 50 Fla. L. Rev. 757.

See generally online: University of Missouri-Columbia, School of I.aw < unww.law.missouri edu/ current/curriculum/coursedescriptions.htm>.

2x. Online, University of Missouri-Columbia, School of Law <www.law.missouri.edu/current/curriculum/ coursedescriptions.htm\#First\%20Year\%20 (ali\%20required)>. 
UMC then offers a wide array of upper year ADR courses, including:

- Arbitration;

- Conflict Theory;

- Dispute Resolution and Lawyering Case Studies;

- Dispute Resolution;

- International Dispute Resolution;

- Mediation;

- Mediation Clinic;

- Cross-Cultural Negotiation;

- Negotiation;

- Public Policy and Dispute Resolution; and

- Pretrial Litigation. ${ }^{207}$

Finally, in terms of graduate programs, UMC "offers a one-year residential Master of Laws in Dispute Resolution (LL.M.) degree. Designed for those with an interest in serious study and practice beyond the J.D. degree, the LL.M. program provides practitioners and scholars with a deeper understanding of theoretical, policy, design and ethical issues in dispute resolution." 208

\section{b. Certificates, Clinics and Programs}

UMC also has several specific LL.B., graduate and professional ADR initiatives, including the:

- Certificate in Dispute Resolution; ${ }^{209}$

- Mediation Clinic; ${ }^{210}$

- Center for the Study of Dispute Resolution; ${ }^{211}$ and

- The Initiative on Mindfulness in Law and Dispute Resolution. ${ }^{212}$

Online: University of Missouri-Columbia, School of Law <www.law.missouri.edu/current/curriculum/ coursedescriptions.htm>.

Online: University of Missouri-Columbia, School of Law <www.law.missouri.edu/lmdr/>.

Online: University of Missouri-Columbia, School of Law <www.law.missouriedu/ prospective/ADR.pdß). According to UMC's web materials, to "receive a Certificate in Dispute Resolution from [UMCl..., a J.D. student must take at least $11-12$ credit hours of dispute resolution courses approved by the Law School. Nine of those credit hours are required core program courses and provide students with a basic understanding of the theory, skills and practice of dispute resolution. Students must take at least 2-3 additional elective hours from among the courses approved for the Certificale program" (ibid. at 2).

The Mediation Clinic, also listed in UMC's course offerings, allows students, during the semester, to "have an opportunity to co-mediate cases in a variety of contexts including cases referred by the Missouri Commission on Human Rights, the Missouri Public Service Commission, small claims courts, local attomeys, and community agencies." Students also "have an opportunity to observe mediations conducted by the Division of Workers Compensation" (online: University of Missouri-Columbia, School of Law <www.law.missouri.edu/current/curriculum/coursedescriptions.htm\$Electives>).

Online: University of Missouri-Columbia, School of Law <www.law.missouri.edu/csdr/index.htm>. Online: University of Missouri-Columbia, School of Law < www.law.missouri.edu/csdr/mindfulness. htm>. The Initiative "is devoted to exploring the potential benefils and risks of mindfulness (and to some extent related contemplative practices, including yoga and other forms of meditation) to members of the legal and dispute resolution professions and those who use or are affected by those professions. 
c. Journal

Missouri also publishes an ADR-focused journal: the Center for Dispute Resolution, Journal of Dispute Resolution. ${ }^{213}$

\section{UNITED KINGDOM}

Three leading English universities were looked at for purposes of this article. As this study reveals, ADR programs continue to be comparatively modest at these institutions.

\section{UNIVERSITY OF OXFORD, FACULTY OF LAW $W^{214}$}

According to its public materials, Oxford does not offer an ADR program. Any meaningful coverage of the topic is included in its "Principles of Civil Procedure" 213 graduate course offering, which includes a section on "Summary Adjudication." However, even that section is primarily focused on traditional summary processes.

\section{UNIVERSITY OF CAMBRIDGE, FACULTY OF LAW 216}

Cambridge has also not developed a focused ADR program. Course offerings that include an ADR component or discussion include:

- Settlement of International Disputes; and

- Family Law. 217

3. LONDON SCHOOL OF ECONOMICS AND POLITICAL SCIENCE (LSE), LAW DEPARTMENT ${ }^{218}$

LSE offers two ADR-related courses:

- Civil Litigation: Processes and Functions (open to graduate - LL.M. - law students); ${ }^{219}$ and

- Alternative Dispute Resolution (open to undergraduate students). ${ }^{220}$

Efforts include research, teaching in law school courses, training through CLE programs, and public service" (ibid.).

213 Online: University of Missouri-Columbia, School of Law <www.law.missouri.edu/csdr/journal.htm>.

214 See online: University of Oxford, Faculty of Law <www.law:ox.ac.uk>.

215 University of Oxford, Faculty of Law, "Student Handbook (Graduate Students) 2004-05" at 58, online: University of Oxford, Faculty of Law <htep://denning.law.ox.ac.uk/published/pghandbook.pd乃. See online: University of Cambridge, Faculty of Law <wnw.law.cam.ac.uk/>.

Ibid.

21x See online: LSE, Law Department <www.Ise.ac.uk/collections/law/>.

219 LSE, "Calendar 2002-2003: Undergraduate Handbook" at 129, online: LSE < www.Ise.ac.uk/resources/ calendar2002-2003/volumeThree.pdis. 


\section{Australia}

Law school ADR programs have a much more expansive hold in Australia than they do in the United Kingdom. As discussed by the Australian Law Reform Commission, "[m]any, if not most, university law schools offer dispute resolution subjects (and sometimes whole postgraduate diplomas or degrees in dispute resolution), although few offer a compulsory 'stand alone' subject for undergraduates in this area."221 The Commission has further indicated that

Those that do include Deakin University and Neweastle University. Almost all of the other law schools in Australia introduce an ADR component into their compulsory first year courses such as Australian Legal System (Bond University), Introduction to Law (Flinders University), Legal Studies (James Cook University). Other law schools offer ADR courses as electives such as Dispute Resolution (Sydney University), Dispute Resolution and Legal Ethics (University of Melbourne), Alternative Dispute Resolution (Murdoch University), Negotiation and Mediation (Northern Territory University) and Dispute Resolution Law (ANU). ${ }^{222}$

Given the very active nature of various Australian ADR programs and course offerings, six of its university programs were reviewed in the context of this article. They are included here given their potential as useful models for further institutional reform thinking in Canada.

\section{BOND UNIVERSITY, SCHOOL OF LAW 223}

\section{a. Dispute Resolution Centre ${ }^{224}$}

According to Bond's public materials, the Dispute Resolution Centre "was established in 1989 and has a national reputation in training, teaching, research and mediation practice. It is based in the Faculty of Law and has an inter-disciplinary focus."223 A primary focus of the teaching of the Centre is in the form of revenue generating continuing legal education courses. 226

\section{b. Courses}

In addition to its Dispute Resolution Centre, Bond offers numerous ADR-related courses in its School of Law, including:

- Legal Skills;

- Negotiation;

- Chinese Negotiation;

- Introduction to Common Law;

- Dispute Systems Design;

- Mediation;

\footnotetext{
221 "ALRC Discussion Paper," supra note 44 at c. 3, para. 3.41 [footnote omitted].

$332 \quad$ lbid. at c. 3, para. 3.41, n. 44

232 See online: Bond University, Faculty of Law <http://bond.edu.au/law/>.

33 Online: Bond University, Faculty of Law <http://bond.edu.au/law/centres/drc/index.hım>.

223 Ibid.

224. bid
} 
- Alternative Dispute Resolution;

- Theory and Principles of Dispute Resolution; and

- Negotiation and Mediation Project. ${ }^{227}$

2. MONASH UNIVERSITY, MONASH LAW SCHOOL 228

a. Courses

Monash's ADR-related courses include:

- Skills, Ethics and Research;

- Lawyers, Ethics and Society;

- International Commercial Arbitration;

- Negotiation and Mediation Law;

- The Justice System, Theory and Practice;

- Administrative Justice Issues in Tribunal Adjudication;

- Commercial Alternative Dispute Resolution;

- International and Domestic Dispute Resolution; and

- Negotiation, Mediation and Process Management Skills. ${ }^{229}$

\section{b. LL.M. (Legal Practice, Skills and Ethics)}

Monash also offers a significant legal practice graduate program. According to its public materials, Monash's LL.M. (LP) program provides "non-law graduates with the theoretical and practical training that leads directly to admission to practice law in Victoria." However, on completion of the course, which is designed to allow professionals "to continue working while they study," certain practice restrictions apply for the first six months of practice..$^{230}$

\section{c. Postgraduate Diploma in Legal Practice, Skills and Ethics (PDLP)}

Monash's PDLP "aims to develop the knowledge and skills required in legal practice and provides an alternative route to admission to practice as a lawyer in Victoria." On successful completion, students "will be admitted to practice as a barrister and solicitor, without the need to do a year of articles." Monash materials note, however, that admission to practice "may be subject to an undertaking to the Supreme Court not to engage in independent private practice (otherwise than as an employee practitioner)" until students "have been employed for a specified period as a legal practitioner."23! 


\section{THE UNJVERSITY OF MELBOURNE, LAW SCHOOL ${ }^{232}$}

\section{a. Law School, LL.B. Courses}

Melbourne's ADR-related course offerings include:

- Dispute Resolution; and

- Legal Ethics. ${ }^{233}$

b. Law School, Graduate Diploma in Dispute Resolution

Melbourne's graduate diploma involves a number of litigation and dispute resolution course offerings, including:

- Alternative Dispute Resolution;

- Avoidance, Management and Resolution of Construction Disputes;

- Commercial Dispute Resolution in Asia;

- Dispute Resolution in the Cyberspace Era;

- International Commercial Arbitration;

- Cross-Cultural Negotiation; and

- International Dispute Settlement. ${ }^{234}$

\section{c. International Conflict Resolution Centre ${ }^{235}$}

Melbourne's Conflict Resolution Centre is a significant teaching and research initiative in the area of dispute resolution, with a particular interest in cultural and regional aspects of conflict. The specific aim of the Centre, which is housed in the University's School of Behavioural Science, is

to research, teach, and disseminate information about the theory and practice of non-violent conflict resolution, with a particular focus on cultural aspects of conflict resolution strategies in Australia and the Asia Pacific Region. This involves interdisciplinary research on alternative dispute resolution strategies such as negotiation and mediation at the international, national, community, and individual levels. Additionally, the Centre provides practical training for professionals who need to expand their conflict resolution skills. An objective of the Centre is to establish and foster links with scholars and practitioners in comparable fields in other countries. ${ }^{236}$

2.2 See online: University of Melbourne, Law <www.law.unimelb.edu.au>>.

in libid.

is See online: University of Melbourne, Law <http:/graduale.law.unimelb.edu.au/index.cfm?objectid= E96BC257-B0D0-AB80-E2FE2906E9408E9\&view=allsubjects\&cid=57>.

23s See online: International Conflict Resolution Centre <www.psych.unimelb.edu.au/icres>.

23. "Centre Profile," online: International Conflict Resolution Centre <www.psych.unimelb.edu.au/irc/ profile.html>. 
4. THE UNIVERSITY OF QUEENSLAND, T.C. BEIRNE SCHOOL OF LAW $\mathbf{w}^{237}$

a. School of Law, LL.B. Courses

Queensland's ADR-related courses include:

- ADR: Theory and Practice;

- Labour Law;

- International Business Transactions;

- Theories in Dispute Resolution; and

- Mediation. ${ }^{238}$

b. LL.M. Courses

Queensland's graduate ADR-related courses include:

- Theories in Dispute Resolution;

- Mediation;

- International Commercial Arbitration;

- Dispute Management Issues; and

- Dispute System Design. ${ }^{239}$

\section{c. Postgraduate Certificate Programs}

Queensland also offers several programs for postgraduate students, including programs that specifically account for a modern legal environment involving a "progressive emergence of the global economy, global corporations and international markets." ${ }^{2+0}$ Courses in these certificate programs include numerous ADR-related courses. ${ }^{241}$

\section{THE UNIVERSITY OF SYDNEY, SYDNEY SCHOOI. OF LAW ${ }^{242}$}

Sydney's ADR-related courses include:

- Dispute Resolution;

- Environmental Dispute Resolution;

- Dispute Resolution in Australia;

- Advocacy, Interviewing and Negotiation; and

217 Sec online: University of Queensland. T.C. Beime School of Law <www.law.uq.edu. au>.

21x See online: University of Queensland. T.C. Beirne School of Law <http://130.102.195.230/files/

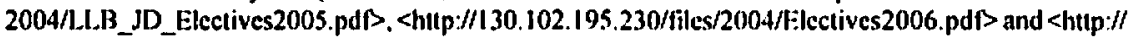
130.102.195.230/files/2005/IntensiveTimetableSem1.pdis. Sec online: University of Queensland. T.C. Beirne School of t.aw shttp://130.102.105.230/files/ 2005/PG_coursework_05.pdis.

2al Online: University of Queensland, T.C. Beirne School of Law <www.law.uq.edu.au/index.htnl? page $=1487 \mid \&$ pid $=|427|>$.

211 Supra note 239.

242 See online: University of Sydney. Sydney Law School < www.law.usyd.edu.au>. 
- International Commercial Arbitration. ${ }^{243}$

\section{THE UNIVERSITY OF ADELAIDE, THE SCHOOL OF LAW 244}

a. Courses

Adelaide's general ADR-related courses include:

- Accreditation for Mediators;

- Altemative Dispute Resolution; and

- Labour and Industrial Relations Law. 245

b. Alternative Dispute Resolution "Special Program"

This program - a "four point elective subject" - is "available to degree and non degree students." ${ }^{246}$ It "focuses on the phenomenon of Alternative Dispute Resolution in society, with particular emphasis on ADR and the law."247 The four modules of this course include: (a) "History, philosophy, and practice of ADR"; (b) "Focus on mediation"; (c) the "changing climate of ADR - International developments - Issues for the future"; and (d) "Project Alliancing and Dispute System Design - a move from conflict resolution to a conflict embracing strategy." 248 Also available through this program is a further, optional "Mediation Accreditation" offering. ${ }^{249}$

\section{E. NEW ZEALAND}

One University in New Zealand was canvassed for purposes of this article.

\section{VICTORIA UNIVERSITY OF WELLINGTON, NEW ZEALAND 250}

a. Faculty of Law

Victoria University of Wellington's ADR-related courses include:

- Arbitration;

- Negotiation and Mediation;

- Dispute Resolution; and

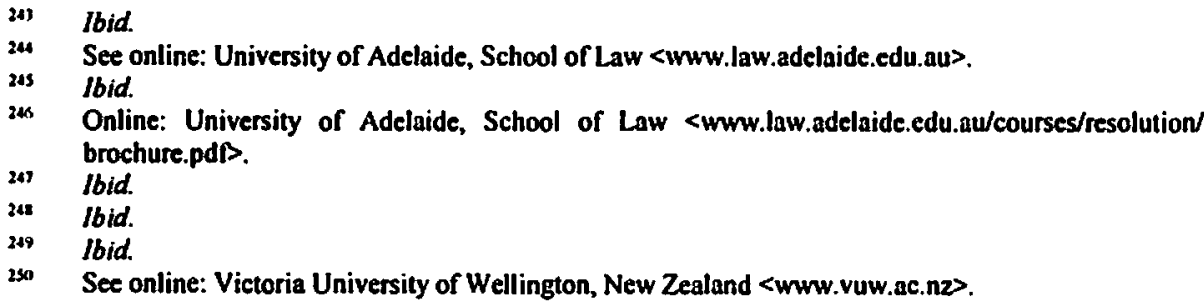




\section{- Graduate Seminar in International Conflict Resolution. ${ }^{251}$}

ADR tools are also taught as part of the International Commercial Law course (graduate level) and the Civil Procedure course. ${ }^{252}$ Further, the Faculty of Law has students writing graduate papers on a "wide range of topics in DR."253

\section{b. New Zealand Centre for Conflict Resolution}

The stated purposes of the Centre are to: (a) "promote the study and practice of dispute resolution, with particular emphasis on negotiation, mediation, and arbitration"; and (b) "promote the comparative, empirical and theoretical study of conflict and its resolution, in both domestic and international contexts." ${ }^{254}$ The Centre also offers professional training and continuing legal education courses. ${ }^{255}$

\section{TAKING Stock: A "Great Beginning" (AND "What IS to Be Done?")}

This part of the paper - borrowing for its subtitle from Lenin, ${ }^{256}$ given the call of the $C B A$ Task Force Report for "revolutionizing" legal education ${ }^{257}$ - (a) evaluates the current landscape of ADR teaching; (b) provides suggestions for further research and teaching initiatives; and (c) addresses potential objections to some of these suggestions, all within the underlying context of exploring and developing ADR as an important tool in the project of improving access to civil justice.

\section{A. A Great Beginning}

As a general matter, particularly given the background context of civil justice reform, the efforts that have been made over the past 10-15 years in the field of ADR have clearly been significant. There is no doubt that there is a direct link between the reform goal of providing alternatives within the civil justice system and the end result of making that system more accessible to more people. For that reason alone we can say that, by increasing alternatives, we have achieved significant success.

Underlying these increased alternatives in the legal marketplace has been a concomitant increase in the amount of teaching and research being conducted in the field. Again, the link is clear between what students are exposed to at law school and what new and future lawyers

Online: University of Victoria University of Wellington, New Zealand, Faculty of Law <www.law.vuw.ac.nZ>. See also "ADR Survey," supra note 14. There is one full-time ADR instructor at the Faculty of Law. There are three practitioners who also teach as part-time/sessional instructors. Ibid.

253. Ibid.

234 Online: Nealand Centre for Conflict Resolution <www.lawschool.vuw.ac.nz/vuw/contenv display_content.cfm?school=law\&id=477>. See also "ADR Survey," supra note 14. lbid.

2sh See V.I.U. Lenin: "A Great Beginning" (July 1919) in Robert C. Tucker, ed., The Lenin Anthology (New York: W.W. Norton \& Company, 1975) 477; "What Is to Be Done? Burning Questions of Our Movement" (March 1902) in ibid. at 12. 
are inclined to develop and accomplish with their clients and through institutional reform at the Bar.

It is this optimistic view of law school training that animates the following question by Carrie Menkel-Meadow: "[S]hould our models conform to what lawyers and teachers can expect to find 'out there' or should we continue to hope that we can inoculate a new generation of lawyers to behave better, by which I mean more effectively, compassionately and efficiently, both for themselves and their clients?"2s8 Coming from the inoculation school, I am of the view that continued thinking and reform about justice system alternatives at the law school level is absolutely critical to the project, ultimately, of increasing overall societal access to that system.

What we have seen to do-date, in my view, can therefore be described as a "great beginning." The Bench and Bar have taken the notion of alternatives seriously, and we are seeing significant developments in the academy that will help to support and develop these initiatives. At the same time, I think there are several issues that need continued and increased focus at the law school level. It is to these issues to which I now turn.

\section{B. What IS TO BE DONE?}

\section{A SENSIBILITY OF OPENNESS TO ALTERNATIVES AND REFORM}

First, and perhaps most important, is the need for an increased pedagogical sensibility that is open to alternative approaches and reforms. While we talk about an ADR "explosion,"359 civil procedure courses continue to be mandatory while ADR courses are, with some significant exceptions, ${ }^{200}$ still comparatively new, experimental, voluntary ${ }^{261}$ and taught, at least in some circumstances, on a pass-fail basis. ${ }^{262}$ As the 2001 curriculum reform project at Toronto found, "[d]espite the importance of ADR, students in law schools across Canada are only exposed to it in a cursory way, as a result of the dominance of the adversarial dispute resolution model. Thus while ADR processes are becoming increasingly pervasive, their importance has yet to be recognized in general in law school curricula." ${ }^{263}$ In essence, we continue to approach the teaching of dispute resolution largely as if over 90 percent of cases

Carric Menkel-Meadow, "I.dwyer Negotiations: Theories and Realities - What We Learn From Mediation" (1993) 56 Mod. L. Rev. 361 at 363. Supra note 25 .

2ai) See generally supra Parts IV-V.

As Catherine Morris has commented, "ADR courses are generally optional, and most substantive law courses still include little or no reflection about dispute resolution. The competitive, adversarial paradigm of dispule resolution is still dominant in Canadian law schools" ("The Moulding of Lawyers," supra note 75 at 279 ).

2 Sec e.g. University of Alberta, Faculty of Law, "Alternative Dispute Resolution" (course description, 2004-2005), online: University of Alberta <irww.law.ualberta.ca/students/Course_Descriptions/ 516BIBEL.pdB. However, in recognition of the importance of this subject area, Alberta's Allernative Dispute Resolution course - as of the 2005-2006 academic year - will no longer be graded on a passfail basis. 
go to trial, not the other way around. ${ }^{26-4}$ As Harvard Professor Albert Sacks commented 20 years ago:

What troubles me is the feeling that our present emphasis on litigation in law school study is not a function of a rounded analysis of the place of litigation in the life of most practicing lawyers or in the provision of legal services generally, or in the development of new law. It may llow, rather, from the interplay of a past pedagogy that focused almost exclusively on appellate litigation and present pressures from the bench and bar that stress visible compelence in the courtroom. ${ }^{263}$

And even though significant progress has been made in North America, Australia and New Zealand since the time Sacks made these comments, ${ }^{266}$ civil procedure continues to be the flagship dispute resolution course at many law schools in those jurisdictions. Elizabeth Schneider's remark that "Civil Procedure is one of the most important courses in the law school curriculum" still largely applies today. ${ }^{267}$

However, underlying this sensibility is the reality, as discussed above, ${ }^{269}$ that ADR has moved to the foreground of student, academic, judicial, government and public needs and demands. Further, if we want to take seriously the reality of settlement figures ${ }^{269}$ and the need to look at alternatives in order better to open the doors of justice to more people in society, then we need at least to align our curricular offerings in order better to reflect the reality of current litigation and to foster the potential for a better, more fair and accessible system of dispute resolution in the future.

The point of this aspect of the discussion is not to advocate for the elimination of traditional course offerings. However, a further sensibility of openness to alternatives and reform is necessary. According to former Chief Justice Dickson, "[t]his will require effort with respect to legal education, both in the law schools and in the profession, in order to increase awareness of the availability of mediation, conciliation and arbitration as possible alternatives from the traditional confrontational attitudes. ${ }^{270}$ It is for this reason that the CBA Task Force Report stated that " $\mathrm{t}] \mathrm{the}$ time has come for a reassessment ... of the underlying principles of the teaching of law and for a redefinition of essential skills ... through

For references to several discussions of domestic and international civil settlement rates, see supra note 43.

Albert M. Sacks, "Legal Education and the Changing Role of Lawyers in Dispule Resolution" (1984) 34 J. Legal Educ. 237 at 244, cited in Sarah Rudolph Cole. Nancy H. Rogers \& Joseph B. Stulberg, "Sustaining Incremental Expansion: Ohio State's Experience in Developing the Dispute Resolution Curriculum" (1998) 50 Fla. L. Rev. 667 at 670. For a discussion of different traditional legal assumptions at law school - in the context of legal writing - sec Katc O'Neill, "Adding an Alternative Dispule Resolution (ADR) Perspective to a Traditional Legal Writing Course" (1998) 50 Fla. L. Rev. 709 at 711.

See generally the programs catalogued in this article, supra Parts IV.V.

Elizabeth M. Schneider, "Structuring Complexity, Disciplinary Reality: The Challenge of Teaching Civil Procedure in a Time of Change" (1993) 59 Brook. I. Rev. 1191 at 1191 ["The Challenge of Teaching Civil Procedure in a Time of Change"].

See supra Pant III.

See supra note 43.

"ADR, The Courts and The Judicial System." supra note 18 at 239. 
improving, perhaps even revolutionizing, legal education."271 We need to continue to take seriously the opportunities and realities of dispute resolution in our modern profession and to modemize further the way legal research and education orient themselves around, as well as influence, those opportunities and realities. Some institutions have made significant strides in this area. Many others, however, have further work to do.

\section{RESEARCH}

\section{a. General}

Canadian research in ADR is gathering steam. ${ }^{272}$ But, as Professor Frank Sander recently commented, even in the United States, ${ }^{273}$ "[d] ]espite all the encouraging developments that have occurred, it is remarkable how little we know about many issues that are basic to ADR."2774 As Sander has further commented, "'[o]n Monday, Wednesday and Friday, I think we've made amazing progress. On Tuesday, Thursday and Saturday, ADR seems more like a grain of sand on the adversary system beach."'275 Michelle LeBaron has made similar comments in Canada: "[s]o much remains to be done and little has been done compared to the number of practice-initiatives in the field." 276

\section{b. Specific Research Areas and Journals}

I agree with Sander and LeBaron. As such, if we are serious about developing ADR further as an integral component of a reformed civil justice system, then there is clearly room for a significant increase in the amount of innovative research that is do be done. ${ }^{277}$ One of the key challenges to many research-based projects in this area is ADR's private, flexible

CBA Task Force Report, supra note 6 at 72 [emphasis omitted], cited supra note 55 and surrounding text. See further Julie Macfarlane, "The Challenge of ADR and Alternate Paradigms of Dispute Resolution: How Should the Law Schools Respond?" (1997) 31 L. Teacher 13; Julie Macfarlane, "The New Advocacy: Implications for Legal Education and Teaching Practice" in Roger Burridge el al., eds., Effective Learning and Teaching in Law (London: Kogan Page, 2002) 164 at 173, cited in Readings and Case Studies, supra note 7 at 79; Roger Fisher \& William Jackson, "Teaching the Skills of Settlement" (1993) 46 SMU L. Rev. 1985; Carrie Menkel-Meadow, "To Solve Problems, Not Make Them: Integrating ADR in the Law School Curriculum" (1993) 46 SMU L. Rev. 1995.

See "Thinking About Dispute Resolution," supra note 7 at 563-64; Readings and Case Studies, supra note 7 at xvii. See further the CFCJ's clearinghouse materials on dispute resolution, online: $\mathrm{CFCJ}$, Civil Justice Clearinghouse <http://karl.srv.ualberta/ca/pls/portal30/aw.menu_search.show>; and online: the University of Victoria <www.dispute.resolution.uvic.ca/publications/order.htm> (discussed supra note 92).

As one recent commentary noted, "much of the available [ADR] material is American in origin" (Readings and Case Studies, ibid.). See also "Thinking About Dispute Resolution," ibid. at 563. For an expansive example of this U.S. research, see online: Harvard Law School, Program on Negotiation <www.pon.harvard.edu/publications/main/index.php3> (see supra note 180) and online: Program on Negotiation at Harvard Law School: Clearinghouse <www.pon.org/>. For a useful international bibliography of dispute resolution literature, see New Zealand Centre for Conflict Resolution, "Bibliography," online: NZCRR <www.lawschool.vuw.ac.nz/vuw/content/display_content. cfm?id=1433> (discussed supra notes 254-55). Frank E.A. Sander, "Some Concluding Thoughts," Symposium, (2002) 17 Ohio St. J. Disp. Resol. 705 at 706.

m" In Michelle LeBaron's view, there are "[h]undreds of areas in need of further research" (ibid.). 
nature, which has resulted in a limited availability of empirical data relating to its processes and results. ADR statistics - even more so than statistics relating to the public civil justice system generally ${ }^{278}$ - have typically been of an ad hoc and anecdotal nature. However, while this lack of systematic data poses obvious challenges, it also provides significant opportunities for future research initiatives - including those of a collaborative and/or interdisciplinary nature - undertaken by full-time academics, LL.B. students and graduate students. Broad research areas that are in need of particular focus, some of which were particularly commented on in the "ADR Survey," 279 include:

- institutional reform, ${ }^{280}$ including systems design and evaluation, ${ }^{281}$ dispute prevention, ${ }^{282}$ the role of mandatory ADR in the traditional court system, ${ }^{283}$ collaborative law initiatives ${ }^{284}$ and online dispute resolution; ${ }^{285}$

As I have said elsewhere, "it is clear that further empirical research and analysis is needed in tracking the business or our civil dispute resolution system." Sec "Globalization, International Human Rights, and Civil Procedure," supra note 5 at 687, n. III and surrounding text.

Supra note 14.

281 For ongoing work in this general area, see, for example, the ongoing work of the $\mathrm{CFCJ}$, cited supra note 2, and ALRI, "Promoting Early Resolution of Disputes," supra note 7. See further Carric MenkelMeadow, "Aha? Is Creativity Possible in Legal Problem Solving and Teachable in Legal Education?" (2001) 6 Harv. Negot. L. Rev. 97. See also Michelle LeBaron, "Teaching Conflict Resolution: Imagination, Intuition, and Innovation" (Workshop Notes) in "Shaping Directions," supra note 63. See e.g. Readings and Case Studies, supra note 7 at c. 7. See also Judith Resnik, "Mediating Preferences: Litigant Preferences for Process and Judicial Preferences for Settlement" (2002) 151 J. Disp. Resol. 155. There is a large body of Canadian and American research conducted over the past 20 years in the area of program evaluation. While a discussion of that research is beyond the scope of this article, the recent work of Macfarlane and Keet - see Learning From Experience, supra note 62 is an example of that research. I am grateful to Michaela Keet for bringing this body of research to my attention.

2nz There is already significant research being done in the area of dispute prevention. See, e.g., the work of the Louis M. Brown Program in Preventive Law, part of California Western School of Law's William J. McGill Center for Creative Problem Solving. According to its web materials, the Brown Program describes preventive law as follows:

The premise of preventive law is that the legal profession can better serve clients by investing resources in consultation and planning rather than relying on litigation as the primary means of addressing legal problems. This theory recognizes that while litigation is sometimes necessary to address past wrongs, the fact that one ends up in an adversarial proceeding may be evidence of a lack of planning or communication. By applying foresight. lawyers may limit the frequency and scope of future legal problems. Preventive law techniques are currently being practiced in the design of sexual harassment policies. in environmental law, in family law (especially estate planning) and in computer law. Virtually any forum setting with avoidable legal problems has room for the practice of preventive law.

Online: California Western School of Law, National Centre for Preventive Law $<$ www.preventivelawyer.org/main/default.asp?pid=brown_program.htm>. For another preventive law initiative, see e.g. the work of the National Centre for Preventive Law (NCPL), also housed at the California Western School of Law. The NCPL is "dedicated to preventing legal risks from becoming legal problems" (NCPL. "Welcome to the NCPL." online: NCPI. <www.preventivelawyer.org' main/default.asp?pid=overview. Jtm >. For general materials on the California Western School of Law, see online: California Western School of Law < www.cwsl.edu/main/home. asp>. I am grateful to Bruce H. Ziff for generally bringing these materials to my attention.

See e.g. Readings and Case Siudies, supra nole 7 at $571-93$; "Promoting Farly Resolution of Disputes," supra note 7.

2at See e.g. John Lande, "Possibilities for Collaborative Law: Ethics and Practice of Lawyer Disqualification and Process Control in a New Model of Lawyering" (2003) 64 Ohio St. L.J. 1315; Ann Osborne, "Collaborative family law requires attitude shifl from practitioners" The Lawyers Weekly (21 January 2005) 10; Cristin Schmitz, "Lawyers Keen on Collaborative Family Law Training" The 
- personal, subjective and contextual factors, including culture, ${ }^{286}$ power, ${ }^{287}$ gender $^{288}$ and human rights; ${ }^{289}$

- professional issues, including professional responsibility and ethics ${ }^{290}$ and advocacy; ; $^{291}$

Lawyers Weekly (10 August 2001) 13.

The internet has become an important tool for the practicing lawyer, including lawyers practicing in the area of dispute resolution. As Monash Law School recognizes, the "internet" has emerged "as a medium for conducting business and practising law" (Monash Law School, cited supra note 228). For a recent discussion of online dispute resolution, see Dave Bilinsky, "Lawyers can't afliord to ignore online ADR providers" The Lavyers Weekly (16 January 2004) 9. For a useful collection of materials discussing online dispute resolution initiatives, see Readings and Case Sudies, supra note 7 at 517-56. See also Joseph W. Goodman, "The Pros and Cons of Online Dispute Resolution: An Assessment of CyberMediation Websites" (2003) Duke L. \& Tech. Rev. 0004, online: Duke Law School <uww.law. duke.edu/journals/dltr/articles/2003dltr0004.htm]>; William K. Slate Il, “Online Dispute Resolution: Click Here to Settle Your Dispute" [2001/2002] Disp. Resol. J. 9; Alain Lempereur, "Innovation in Teaching Negotiation Towards a Relevant Use of Multimedia Tools" (2004) 9 Inl'I Neg. 14I ["Innovation in Teaching Negotiation"]. See also, generally, University of Massachusetts Amlerst, The Center for Information Technology and Dispule Resolution, supra nole 171.

Sec e.g. Readings and Case Studies, supra note 7 at 42-68, 204-209. See also Calherine E. Bell \& David Kalıane, eds., Intercultural Dispute Resolution in Aboriginal Contexts (Vancouver: University of British Columbia Press, 2004) [interculitural Dispute Resolution in Aboriginal Contexts]; Michelle LeBaron \& Zena D. Zumeta, "Windows on Diversity: Lawyers, Culture, and Mediation Practice" (2003) 20 Conflict Res. Q. 463; Michelle LeBaron, Bridging Troubled Waters: Conflict Resolution from the Hearf (San Francisco: Jossey Bass, 2002). There are clearly very topical issues dealing with ADR and culture that need to be addressed immediately. One only need look as far as the current debate in Ontario about Sharia-based tribunals to see that further thinking is needed. On this issue, sce e.g. the "Boyd Report," supra note 63. In other areas, significant use of ADR is being made in the current resolution of thousands of residential school claims in Canada. For general information on this initiative, see e.g. Government of Canada, "Indian Residential Schools Resolution Canada," online: Government of Canada <www.irst-rqpi.gc.ca/english/index.hıml>. See also Losi Young, "8 Minule Round Table" in "Shaping Directions," supra note 63; Jennifer J. Llewellyn, "Dealing With the Legacy of Native Residential School Abuse in Canada: Litigation, ADR, and Restorative Justice" (2002) 52 U.T.L.J. 253 ["Litigation, ADR, and Restorative Justice"]. See also Intercullural Dispute Resolution in Aboriginal Contexts, ibid,; Cynthia Ford, "Including Indian Law in a Traditional Civil Procedure Course: A Reprise, Five Years Later" (2001) 37 Tulsa L. Rev. 485 ["Including Indian Law in a Traditional Civil Procedure.Course"].

See e.g. Readings and Case Studies, supra note 7 at 209-15, 459-74; lan Morrison \& Janet Mosher, "Barriers to Access to Civil Justice for Disadvantaged Groups" in Ontario Law Reform Commission, Rethinking Civil Sustice: Research Studies for the Civil Justice Review (Toronto: Ontario Law Reform Commission, 1996) 637 at 663-74 ["Barriers to Access to Civil Justice for Disadvantaged Groups"] in The Civil Litigation Process, supra note 26 at 592.96.

See Readings and Case Studies, ibid. at 58-64, 180-204. See further Judith Resnik, "Revising the Canon: Feminist Help in Teaching Procedure" (1993) 61 U. Cin. L. Rev. 1181 ["Feminist Help in Teaching Procedure"]; Elizabeth M. Schneider, "Gendering and Engendering Process" (1993) 61 U. Cin. L. Rev. 1223 ["Gendering and Engendering Process"].

Mediation is becoming an increasingly important tool in resolving domestic human rights complaints. See e.g. Bill 64, Human Rights Code Amendment Acl, 3d Sess., 37th Parl., British Columbia, 2002 (as passed by the Legislative Assembly on 29 October 2002). As Black and Bryden have commented, potential power imbalances in these types of proceedings are of significant importance, polentially more so than in processes involving business disputes. See William Black \& Philip Bryden, "Mediation as a Tool for Resolving Human Rights Disputes" (Workshop Notes) in "Shaping Directions," supra nole 63.

In Canada, lawyers' ethical responsibilities in the context of ADR are primarily governed in various ways by the different provincial professional conduct codes across the country. In Ontario, for example, r. 2.02(3) of the Rules of Professional Conduct provides that: "The lawyer shall consider the use of alternative dispute resolution (ADR) for every dispute, and, if appropriate, the lawyer shall inform the client of ADR options and, if so instructed, take steps to pursue those options." (Rules of Professional Conduct (adopted 22 June 2000, in effect I November 2000, as amended), online: Law Society of 
and

- broad social and political issues, including globalization, ${ }^{292}$ privatization and ADR's impact on the rule of law. ${ }^{293}$

Upper Canada <www.lsuc.on.ca/services/contents/nule2.jsp\#2.02(3)>). See also ibid., 5.4 .07 ("Lawyers as Mediators"), online: Law Society of Upper Canada <www.Isuc.on.ca/services/contents/rules4. jsp\#4.07>. In Nova Scotia, the Legal Ethics \& Professional Conduct Handbook, Commentary 10.2A, provides, unlike Ontario, that lawyers "should," not "shall," consider ADR: "The lawyer should consider the appropriateness of alternate dispute resolution (ADR) to the resolution of issues in every case and, if appropriate, the lawyer should inform the client of ADR options and, if so instructed, take steps to pursue those options"( Legal Elhics \& Professional Conduct Handbook, online: Nova Scotia Barristers' Society <www.nsbs.ns.ca/handbook/chapter l0.html>). Alberta's approach, similar to that of Nova Scotia, provides that: "In addition to the conventional legal process, a lawyer should consider alternative dispute resolution" (Code of Professional Conduct (23 June 2004) c. 10 at Commentary 16. online: Law Society of Alberta <www. lawsocietyalberta.com/files/code.pdP). See also ibid. at $c$. II ("Lawyer as Negotiator"), which contains comparatively extensive provisions dealing with ethical requirements in the context of lawyers and negotiation. The issue of ethics and ADR is also currently being examined in British Columbia. See e.g. the Law Society of British Columbia, Alternative Disputc Resolution Task Force, online: the Law Society of British Columbia <www.lawsocicly. bc.ca/about_law_society/body_about_committees.htmI\#AlternativeDisputeResolution>. 1:inally, the CBA Code of Professional Conduct has recently been amended and contains - in c. 9, Commentary 8 ("Encouraging Settlements and Alternative Dispute Resolution") - similar language to that of the Nova Scotia and Alberta Codes. See CBA, online: CBA <www. cba.org/CBA/resolutions/pdl/04-01A.pdB. For a general discussion, see The Civil Litigation Process, supra note 26 at 213-16.

Notwithstanding these existing jurisdietional provisions, ethics in the context of ADR and access to justice is a research area that is in need of particular focus. In addition to my own interest in the area, 1 say this based on two specific statements: (a) the Law Commission of Canada's recent recommendation that provincial codes of professional conduct be reviewed in light of modern dispute resolution demands (Transforming Relationships, supra notc 59 at 215-16); and (b) the CBA Task Force's easlier statement that the "adoption of a dispute resolution approach" to "litigation practice" amounts to a "new professional obligation" (CBA Task force Report. supra note 6 at 64). The CBA's statement is supported by former Chief Justice Brian Dickson, who argued that protecting and fostering access to justice is not just about adequate institutional design. Rather, it is a lawyer's "professional duty, as an officer of the court, to ensure that matlers proceed as expeditiously as possible" ("Access to Justice," supra note 2). For Dickson, this may mean going further than the basics set out in various code provisions: "Whilc the Canadian Bar Association's Code of Professional Conduct states that lawyers should encourage clients to settle disputes on a reasonable basis and avoid useless legal proceedings, lawyers need to go further and should consider how ADR may best serve their clients" ("ADR, The Courts and The Judicial System," supra note 18 at 238 [footnote omitted]). If this is right (and $I$ think it is), then on what basis, and under what authority and sanction it should occur, are all issues that need further exploration and thinking.

Some work is clearly already being done in the area. See e.g. Carrie Menkel-Meadow, "Ethics in ADR: The Many 'Cs' of Professional Responsibility and Dispute Resolution" (200I) 28 Fordham Urb. L.J. 979; Readings and Case Studies, supra note 7 at 258-80, 482-515; Van A. Anderson, "Alternative Dispute Resolution and Professional Responsibility in South Carolina: A Changing Landscape" (2003) 55 S.C.L. Rev. 191. However, traditional approaches to ethical research and education still dominate. For example, in the most recent casebook dedicated to professional ethics in Canada, there appears to be no mention of ADR or its ethical implications, either on its own or as a comparative matter to more traditional approaches. See Randal N.M. Graham, Legal Ethics: Theories, Cases. and Professional Regulasion (Toronto: Emond Montgomery, 2004) at ix-xii (Table of Contents) and $617-22$ (Index). For a current example of this kind of work, see e.g. Monash Law School's LL.M. program focusing on legal practice, skills and thics, supra note 230 and surrounding text.

242 For an example of current work being done in this area, see "Negotiation, Mediation, Globatization Protests and Police," supra note 7.

291 See e.g. Owen M. Fiss, "Against Settlement" (1984) 93 Yale L.J. 1073 ["Against Settlement"]; Chris A. Carr \& Michael R. Jencks, "The Privatization of Business and Commercial Dispute Resolution: A Misguided Policy Decision" (1999-2000) 88 Ky. L.J. 183 ["The Privatization of Business and Commercial Dispute Resolution"]; "Reflections on Judicial ADR," supra note 20; Andrew J. Cannon, 
Further, given the current and growing amount of Canadian ADR scholarship that is being produced ${ }^{294}$ together with the potential future amount that is contemplated by the abovenoted research areas, there is clearly room for a topic-specific law journal. As one recent report commented: "In the past three years ... calls for a dedicated Canadian dispute resolution journal have continued to grow." ${ }^{295}$ This could be produced in several ways, including as a faculty-connected, student-run journal, or as part of a centre or dispute resolution institute. ${ }^{296}$

\section{TEACHING}

\section{a. Institutes and Collaboration}

As the "CBA Survey" recognized, there are clearly going to be different approaches to the way ADR is taught at different law schools. ${ }^{297}$ Three general models catalogued in this article include: (a) an institute complemented by faculty courses; ${ }^{298}$ (b) ADR taught through an integrated, pervasive approach; ${ }^{299}$ and (c) a more traditional course-based approach. ${ }^{300}$

Obviously creating research institutes or special programs, in addition to course-based offerings (either integrated or traditional), has the potential of leading to significant developments in terms of focused research and productivity, teaching, student involvement and increased faculty-community collaboration and exposure (national and international). This has certainly been the experience at institutions such as Victoria, UBC, Harvard, Stanford, Bond and Victoria University of Wellington.

However, given varying institutional interests and resources, I recognize that focused ADR centres may not be set up at every faculty of law. To the extent that faculties are not prepared, or in the position, to set up designated institutes or programs of their own; collaborative initiatives should be considered by instructors and researchers working across the discipline. ${ }^{301}$ This was clearly the idea behind the CBA's suggestion that "[i]t may be useful

"A Pluralism of Private Courts" (2004) 23 C.J.Q. 309; "Barriers to Access to Civil Justice for Disadvantaged Groups," supra note 287.

$2 \% 4$ Discussed supra note 272 and surrounding text.

295 Readings and Case Studies, supra note 7 at xvii.

:\% For examples of these sorts of journals, see those produced in connection with Harvard's various ADR programs, supra notes 183-84 and surrounding text, and Missouri's Center for Dispute Resolution, Journal of Dispute Resolution, supra note 213 and surrounding text.

297 Discussed supra note 83 and surrounding text.

298 In Canada, see supra Part IV.B. Internationally, see Harvard, supra note 172; Stanford, supra note 189; Bond, supra note 223; and Melbourne, supra note 232.

299 In Canada, see supra Part IV.C. Internationally, see Missouri, supra note 203 (Missouri could also be catalogued together with international institutions that have dedicated centres as well).

4x) In Canada, see supra Part IV.D. Internationally, see NYU, supra note 185; Berkeley, supra nole 198: Monash, supra note 228; Sydney, supra note 242; Adelaide, supra note 244; Vicioria University of Wellington, supra note 250 .

301 For an excellent example and source of collaborative initiatives and results, see "Symposium: Dispute Resolution in the Law School Curriculum," supra note 29, and in particular, "A Report on a Collaboration with Six Law Schools," supra note 204. 
for law schools and other legal educators to collaborate on developing new programs." 302 Research colloquia, visiting lectures, international initiatives, ${ }^{303}$ shared research and collaborative funding proposals are certainly all possibilities of this kind of exercise. For example, use should be made by researchers and instructors of the extensive and ongoing empirical research and analysis being done by the $\mathrm{CFCJ}^{304}$ in the area of civil justice reform, including dispute resolution. It is also this kind of collaborative approach, from an international perspective, that is the basis of the "objective" of the University of Melbourne - through its International Conflict Resolution Centre - "to establish and foster links with scholars and practitioners in comparable fields in other countries." 30 s

All of these initiatives - whether through dedicated centres or collaborative research and/or teaching efforts - will enhance our overall collective understanding of the use and power of ADR as a tool for providing varied, innovative options for resolving disputes and thereby assisting with ongoing domestic and international reform projects seeking to make justice more accessible for all.

\section{b. Integrated or Traditional Approach?}

In terms of specific course approaches, there has been a significant amount of success at North American institutions that have adopted an integrated, pervasive method of teaching ADR. These integrated ADR approaches have in turn benefited from the experiences of various institutional efforts to teach professional responsibility by the pervasive method. ${ }^{306}$ Examples of integrated ADR approaches include Saskatchewan, Ottawa and MissouriColumbia. ${ }^{307}$ Ottawa's program, in particular, was cited by the Australian Law Reform Commission as a particularly useful teaching model. ${ }^{309}$

CBA Task Force Report, supra note 6 at 64 . An example of this type of cooperation was the assistance that I gratefully received from Michaela Keet at the University of Saskatchewan in the context of my preparation of a dispute resolution report for the University of Alberta (discussed supra note *). See "Keet Conversation," supra note 114. "Saskatchewan Review Project," supra note 80.

sut For example, over the past two years, I have been involved in dispute resolution reform initiatives in Japan, in the context of law school reform, and in the Federation of Bosnia and Ilerzegovina and the Republic of Srpska, in the context of judicial training in a new civil justice system, including, in particular, the tools of JDR and other pre-trial reform initiatives. My international involvement will also extend to China in 2005.

24. Sec supra note 2.

uns See supra note 236 and surrounding text.

ur. See supra note 87 and surrounding text and infra notes $315-17$ and surrounding text.

:a7 Supra notes $114,118,203$ and surrounding text.

unt As the Commission commented:

The University of Ottawa ... has a first year program which trains students in mediation case analysis, effective client representation and developing specialised strategies to solve disputes creatively. The teaching method involves the use of case mediation exercises and student interaction with local members of the bar. Dispute resolution is also integrated into the substantive materials of the first year contracts and property classes. In the second and third year of the undergraduate degree at Ottawa, students must also complete a mandatory skills unit in mooting. trial advocacy, or interviewing. counselling and negotiation. Such courses could usefully be adapted in Australia ("ALRC Discussion Paper." supra nole 44 at c. 3. para. 3.43).

See further "Symposium: Dispute Resolution in the Law School Curriculum," supra note 29. 
There are clear benefits to the pervasive approach. ${ }^{309}$ Moving ADR teaching into the heart of the substantive law curriculum takes seriously the rise of the ADR movement ${ }^{310}$ and its place in mainstream legal education vis-à-vis other, traditional process-oriented courses. It also takes seriously the project of pushing the agenda of alternative processes for the resolution of disputes, which are in turn designed to play a role in the overall project of improving access to affordable civil justice. ${ }^{311}$ Further, from a pedagogical perspective, it provides significant opportunities to contextualize legal education by combining substance and process with theory and practice, a combination designed to work to the benefit of all aspects of the law school curriculum. Finally, it addresses mounting student demands for practical, skills-based courses in general, and ADR training in particular. ${ }^{312}$

Notwithstanding these benefits, however, there are significant downsides to the pervasive approach. While I am not opposed in theory to integration, my concern about this approach is that ADR - through an effort in mainstreaming - in fact faces the problem of becoming further, not less marginalized. This problem potentially occurs in several ways. First, not all faculty members are experts (or even competent) in teaching ADR. As Katheryn Dutenhaver has commented, the "greatest barrier to integrating dispute resolution into existing courses" is an institution's current faculty's "lack of knowledge about dispute resolution and its pedagogy." ${ }^{313}$ This point about required expertise, as a general matter, makes intuitive sense. It also is particularly present in the context of teaching dispute resolution. Paul Brest identifies two problems here:

One ... is that to take something scriously as an intellectual subject means getting a command of a quite substantial body of knowledge, which is every bit as complex, every bit as analytically demand ing, as knowing contracts, property, or torts.... In some sense, the more seriously we take a subject, the more we should wonder about asking somebody to do a snippet in the first year course... [The other] pedagogie point ... [is] that the pedagogies we use in dispute resolution require skills unfamiliar to many law professors. Teaching through simulation seems a risky endeavor for many instructors... Not everyone has the courage and those skills. $^{314}$

Second, by making ADR a mandatory part of first year as an attachment to, for example, a course in contracts, it becomes one or two of twelve units that needs to be covered in a given core offering. In this sense, it is given significantly less coverage than it would be through a course of its own. (Ottawa, for example, seeks to avoid this marginalization by

For general, very persuasive discussions on the issue of integration, see e.g. "Symposium: Dispute Resolution in the Law School Curriculum," ibid.; "Keet Conversation," supra note I 14; "Saskatchewan Review Project," supra note 80.

See supra Part II.A.

See supra Part II.

See supra notes 76-79 and surrounding text.

"Dispute Resolution and Its Purpose," supra note 204 at 729.

Paul Brest, "The Alternative Dispute Resolution Grab Bag: Complementary Curriculum, Collaboration, and the Pervasive Method" (1998) 50 Fla. L. Rev. 753 at 754-75 [footnote omitted] ["The Alternative Dispute Resolution Grab Bag"]. In connection with these two points, Brest references two further commentaries: Lea B. Vaughn, "Integrating Altemative Dispute Resolution (ADR) into the Curriculum at the University of Washington School of Law: A Report and Reflections" (1998) 50 Fla. L. Rev. 679 at 699.700 ["Integrating Alternative Dispute Resolution (ADR) into the Curriculum"]; and "Teaching Dispute Resolution in the First Year of Law School," supra note 204 at 613-14. 
combining both dedicated and pervasive mandatory dispute resolution coverage in the first year, supplemented by further upper year offerings.)

Third, by making dispute resolution one of many aspects of a traditional core course, even if an important aspect, a strong signal is sent to students that dispute resolution is important by way of appendage only, or put another way, in the eyes of first year students, it does not deserve a course of its own. The point has been further made by Paul Brest, who compared the issue with the difficulty Stanford had in implementing ethics by the pervasive method in its first year program." As Brest remarked, "[i]f a professor does not want to teach ethics [or ADR] as part of his or her torts or criminal law or constitutional law course, the ways of subverting it are myriad." 316 Further, "[t]here is no worse message you can give to students than one faculty member did when he announced: 'Here comes the sermon."'317

Fourth, having attended numerous law faculty council discussions regarding curriculum reform, without a dedicated faculty champion and strong faculty-wide support, curriculum reform that requires faculty members to include a topic beyond the scope of their direct expertise or interest is difficult at best. ${ }^{313}$ This issue - at core one of academic ability and freedom - is compounded by the fact that, by adding ADR topics to a first year contracts course, for example, the contracts instructor will be forced to delete other sections of the course that would otherwise be included. As most law school professors will agree, time is already at a premium. ${ }^{319}$

In an effort to avoid many of these problems, my preference is to maintain a traditional, course-based approach to dispute resolution teaching, supplemented (where possible) by integrated, pervasive efforts. ${ }^{320}$ This preference benefits from, and builds on, the approaches used, for example, at Victoria, UBC, Ottawa, Harvard and a number of the Australian programs discussed above. ${ }^{321}$ In a nutshell, 1 think the right amount/balance of dispute resolution training (assuming no dedicated ADR institute) would include the following elements:

- a mandatory, general first year legal process course that would introduce students to the broad issues involved with dispute resolution, ethics, access to civil justice, reform and the general legal process; ${ }^{322}$

- efforts to integrate, where appropriate, dispute resolution issues into other core first

its "The Alternative Dispute Resolution Grab Bag," ibid. at 754.

ine. Ibid.

117 Ibid.

"ix For a brief discussion of this potential problem, see ibid. at 754. See also "Keet Conversation," supra nole 114.

I" For a brief discussion of curriculum reform experiences on similar issues, see "Integrating Alternative Dispute Resolution (ADR) into the Curriculum," supra note 314 at 699-700.

130 My thinking in this section has benefited from very helpful comments from Michaela Keet who, as a founding faculty member of Saskatchewan's pervasive program, ultimately takes a different view from me on the merits of pervasive and course-based approaches.

321 See generally supra notes 94, 103, 118, 172 and Part V.D.

132 Toronto, for example, offers - in its first year Legal Process course - a similar offering to this suggestion. Discussed supra note 147 and surrounding text. 
year (and other upper year) courses; 323

- a required upper year civil dispute resolution course - combining both civil procedure and ADR - that builds on the more general, theoretical first year legal process course; ${ }^{324}$

- other optional upper year dispute resolution offerings, ${ }^{325}$ including a traditional civil procedure course ${ }^{326}$ (that, together, perhaps make up a dispute resolution "stream"327);

- modes of evaluation that would include, at least once in a student's law school career: (a) an essay on dispute resolution, access and reform; (b) a written advocacy piece (in the form of a factum for example) dealing with poverty and/or some form of access issue; and (c) an opportunity for oral dispute resolution advocacy with adequate supervised instruction and feedback (using video review equipment, etc.); and

- voluntary (but strongly encouraged) clinical or placement opportunities for those interested in pursuing further the practical aspects of dispute resolution, ethics and access to justice. ${ }^{328}$

There are certainly other ways that ADR courses could be grouped and offered. Further, it is recognized that some of these elements are already in place at some institutions. However, this proposed model would, as a general matter: (a) avoid a number of the potential

323

This suggestion - admittedly ad hoc, although preferably institutionalized - would supplement and contextualize the required legal process course. Ottawa provides a useful example of pervasive integration: supra note 118.

This suggested course would be a lecture-based course that could ideally be supplemented by weekly small-group, skills-based sessions led by practitioners (in the way that some Osgoode instructors have offered small group civil procedure sections). Sec e.g. Osgoode Hall Law School, "First Year Description" (Civil Procedure), supra note 1SI.

In addition to the courses catalogued with the various institutions discussed in this article (supra Parts IV-V), see the suggested list of courses set our below (infra Part VI.B.3.c.).

For a useful collection of anicles looking at the perennially difficult issues surrounding the teaching of civil procedure, see the Winter 2003 edition (vol. 47) of the Saint Louis University Law Journal. See also Stephen N. Subrin, "Teaching Civil Procedure While You Watch lt Disintegrate" (1993) 59 Brook. L. Rev. 1155; Kevin R. Johnson, "Integrating Racial Justice into the Civil Procedure Survey Course" (2004) 54 J. Legal Educ. 242; William R. Slomanson, "State Civil Procedure Plea" (2004) 54 J. Legal Educ. 235; "The Challenge of Teaching Civil Procedure in a Time of Change," supra note 267; "Feminist Help in Teaching Procedure," supra note 288; "Gendering and Engendering Process," supra note 288; Elizabeth M. Schneider, "Rethinking the Teaching of Civil Procedure" (1987) 37 J. I Legal Educ. 41; Stephen J. Shapiro, "Teaching First-Year Civil Procedure and Other Introductory Courses By the Problem Method" (2000) 34 Creighton L. Rev. 245; "Including Indian Law in a Traditional Civil Procedure Course," supra note 286; Jeffrey A. Parness, "Evolving Views or Civil Litigation: Future Civil Procedure Courses" (1999) 31 Ariz. St. L.J. 945; Mary Brigid McManamon, "The History of the Civil Procedure Course: $\Lambda$ Study in Evolving Pedagogy" (1998) 30 Ariz. St. L.J. 397: Jonathan L. Entin, "Scholarship Aboul Teaching" (1998) 73 Chicago-Kent L. Rev. 847; Raleigh Hannah Levine, "Of Learning Civil Procedure, Practicing Civil Practice, and Studying A Civil Action: A Low-Cost Proposal to Introduce First-Year Law Students to the Neglected MacCrate Skills" (2000) 31 Seton Hall L. Rev. 479; Paul Barron. "Can Anything Be Done to Make the Upper-Level Law School Courses More Interesting?" (1996) 70 Tul. L. Rev. 1881; Alan M. Lerner, "Law \& Lawyering in the Work Place: Building Better Lawyers by Teaching Students to Exercise Critical Judgment as Creative Problem Solvers" (1999) 32 Akson L. Rev. 107; Arturo Lopez Torres, "MacCrate Goes to Law School: An Annotated Bibliography of Methods of Teaching Lawyering Skills in the Classroom" (1998) 77 Neb. L. Rev. 132; "Globalization, International Human Rights, and Civil Procedure," supra note 5; Kent Roach, "Teaching Procedures: The Fiss/Weinrib Debale in Praclice" (1991) 41 U.T.L.J. 247.

See e.g. the streams/programs offered by UBC, Osgoode, McGill, Berkeley, Missouri, and Adelaide, discussed supra notes 103, 150, 159, 198, 203 and 244 and surrounding text.

See the further discussion below on clinical offerings, infra Part VI.B.4.c. 
pitfalls of other approaches; ${ }^{329}$ (b) address in a systematic fashion the ongoing issues and recommendations made by the various domestic and international civil justice system reform proposals discussed in this article; ${ }^{330}$ (c) provide an adequate balance of theory and practice; ${ }^{331}$ (d) provide a solid foundation for encouraging current and future thinking by students and faculty in the area of dispute resolution and access; and (e) provide an exciting, stimulating and energizing environment that would maximize positive opportunities for student involvement, collaboration and interest in the field and in the potential pursuit of careers in this ever expanding area of the legal profession.

\section{c. Specific Modern Courses}

Catalogued above are the various ADR course offerings currently being listed at the Canadian and international programs discussed in this article. ${ }^{332}$ Set out below is a suggested selection of courses, influenced by the various courses currently being taught, domestically and internationally, together with suggestions received through the "ADR Survey," which 1 think, in an effort to foster further understanding and thinking in the area of ADR and access, should ideally become part of regular law school dispute resolution offerings: ${ }^{33}$

- ADR, the Courts and the Administration of Justice; ${ }^{34}$

- Advanced Topics in ADR; ${ }^{335}$

- Dispute Prevention;336

- Restorative Justice in Canada; ${ }^{337}$

- So You Want a Career in ADR?; ${ }^{338}$

Discussed supra Part VI.B.3.b.

Discussed supra Part II.

Discussed infra note 377 and surrounding text.

See supra Parts IV.V.

This list could obviously include other courses in the area of ADR and access. It also, purposely, does not contemplate some of the other mainstream dispute resolution courses, currently being offered, such as international dispute resolution and international commercial arbitration, etc.

This course - both theoretical and practical - would look at current court-based ADR initiatives in Canada and elsewhere. It would also look at strategic lawyering decisions, both in terms of decisions about what processes work for what disputes, and also what techniques within those processes work for different disputes and parties. Ethics would form a meaningful part of this course. See e.g. the teaching initiatives in this area at UBC. supra note 103: Osgoode, supra note 150: and Monash, supra note 228 and surtounding text.

This advanced theory-based course - building on a basic ADR course - would look at specific topics including: dispute prevention; dispute resolution clauses in commercial contracts; ethics; gender; culture; online dispute resolution; dispute resolution systems design; and globalization in the context of ADR and the changing nature of the profession. See e.g. the teaching initiatives in this area at Toronto, supra note 145; Harvard, supra note 172; and Stanford, supra note 189 and surrounding text. See earlier discussion on dispute prevention initiatives, supra note 282.

For recent examples of research in this area, see Annalise E. Acom, Compulsory Compassion: A Crisique of Restorative Justice (Vancouver: University of British Columbia Press, 2004): "Litigation. ADR, and Restorative Justice," supra note 286.

This course - the title for which is adopted from a course al Harvard Law School entitled "So You Want to Be a Lawyer?" - would: seek to provide students with an opportunity to look at current and potential future career options in the legal profession and elsewhere that focus primarily on ADR: bring in speakers from different ADR-related careers; and expose students - through experiential, "clinicstyle" learning - to one or more ADR-related career options. For a useful discussion on the topic, see Genevieve A. Chornenki, "Mediation: Entry Point Not Destination" (1999) 17 Windsor Y.B. Access Just. 26I. See also Suzanne J. Schmitz, "What Should We Teach in ADR Courses? Concepts and Skills 
- The Privatization and Globalization of Dispute Resolution; ${ }^{339}$

- Ethics in Dispute Resolution; ${ }^{340}$

- Online Dispute Resolution; ${ }^{34}$

- Dispute Resolution Skills and Advocacy; ${ }^{342}$

- So You Want to Be a Mediator?; ${ }^{343}$

- Power, Gender and Culture in Dispute Resolution; ${ }^{344}$

- Disputing Labour Relations;; ${ }^{345}$

- Disputing Family Relations; ${ }^{346}$

- Dispute Resolution and Indigenous Peoples; ${ }^{347}$

- Dispute Resolution: Theory and Practice; $;^{3+8}$

- Dispute Avoidance: Dispute Resolution for the Commercial Lawyer; and

- Access to Justice, Public Policy and Dispute Resolution. ${ }^{349}$

\section{OTHER ADR INITIATIVES}

\section{a. Moots}

In addition to traditional mooting exercises, advocacy exercises that employ ADR skills and thinking should be encouraged and developed. An example of this type of exercise is the

for Lawyers Representing Clients in Mediation" (2001) 6 Harv. Negot. L. Rev. 189.

This course would look at current trends of up and downloading dispute resolution (to international tribunals and to domestic privatc arbitration and mediation panels) and the concomitant impact that these trends have on access to, and the administration of, justice both nationally and internationally. Sec the earlier discussion on research in the area of ADR and ethics, supra note 290 and surrounding text. See further, e.g., the teaching initiatives in this area at Stanford, supra note 189; Monash, supra note 228; Melbourne, supra note 232 and surrounding text.

See e.g. Melbourne's teaching initiatives in this area, bbid. and surrounding text. See also "Innovation in Tenching Negotiation," supra note 285 at 142-49.

For a look at some of these issues, see e.g. "From Litigation to Mediation," supra note 63. See further, e.g., the teaching initiatives in this area at Windsor, supra note 138; Ottawa, supra note 118; Alberta, supra note 124; Calgary, supra notc 129; Osgoode, supra note 150; Queen's, supra note 157; Harvard, supra note 172; NYU, supra note 185; Chicago, supra note 187; Stanford, supra note 189; Missouri, supra notc 203; Monash, supra note 228; Queensland, supra note 237; Sydney, supra note 242 and surrounding lext.

Sec e.g. Adelaide's teaching initiatives in this area, supra nole 244 and surrounding text.

See c.g. the teaching initiatives in this area at Alberta, supra note 124; Missouri, supra note 203; and Melbourne, supra note 232 and surrounding text.

See e.g. the teaching initiatives in this area at Victoria, supra note 94; UBC, supra note 103; Toronto. supra note 145; Saskatchewan, supra note 114; Ottawa, supra note 118: Alberta, ibid; Calgary, supra note 129; Manitoba, supra note 136; Queen's, supra note 157; UNB, supra note 162; Chicago, supra note 187; Adelaide, supra notc 244 and surrounding text.

Sec e.g. the teaching initiatives in this asea at Dalhousic, supra note 112; Ottawa, ibid; and Calgary, ibid. and surrounding text.

Catherine Bell, in her introductory ADR course at Alberta, includes a section on dispute resolution in Aboriginal contexts. See Callierine Bell, "Altemative Dispute Resolution," online: University of Alberla, I'aculty of Law <inww.law.ualberta.ca/students/Course_Descriptions/516B1BEL.pdß. See also UBC's "Topics in Litigation, Dispute Resolution \& Administration of Justice" course, supra note 103 and surrounding text.

Sec e.g. the teaching initiatives in this area at Victoria, supra note 94; Toronto, supra note 145; Ottawa, supra note 118; Manitoba, supra note 136: Osgoode, supra note 150, Harvard, supra note 172; Missouri, supra nole 203: Bond, supra note 223; Queensland, supra note 237 and surrounding text. Sec e.g. the teaching initiatives in this area at Victoria, ibid; Windsor, supra note 138; Missouri, ibid. and surrounding text. 
Fraser, Milner, Casgrain Negotiation Competition. ${ }^{350}$ These sorts of exercises: (a) allow for further student skills training in the area of ADR; (b) raise awareness of and interest in ADR issues; and (c) related to the previous benefit, further mainstream the ADR movement in the minds of law students and future lawyers.

\section{b. Student Awards and Fellowships}

Incentives, in the form of general cash prizes or other merit-based benefits, should be awarded annually in law faculties for the best paper - written by an LL.B. or LL.M. student in the context of a course or an independent study project - in the general area of dispute resolution and access. Stanford's Center for Conflict and Negotiation, Richard S. Goldsmith Award is an example of this type of initiative. ${ }^{351}$

Further, research fellowships - along the lines of Harvard's Program on Negotiation Graduate Research Fellowships ${ }^{332}$ and the various fellowships offered at Stanford in the area of dispute resolution ${ }^{333}$ - will attract further graduate students and research in the fields of ADR, the administration of civil justice and access.

\section{c. Clinics and Internships}

Law schools, through clinical programs and/or internship programs, can significantly add to the immediate project of ADR training and the broader project of assisting in improving access to justice for all. As Suzanne J. Schmitz recently commented in the U.S., "Law schools across the nation can significantly contribute to improving the public's access to the justice system" through the development of "[m]ediation programs," which "enable more people to experience justice." 354 And the benefits of these clinical programs do not simply flow one way. As Schmitz further comments, faculty members and students involved in clinical ADR programs, logether with faculties generally as institutions, "have gained perhaps as much as they have contributed." ${ }^{\text {"ss }}$

These sorts of initiatives can be provided as stand-alone programs or as partnerships with other existing community programs including human rights organizations, social service offices, legal aid clinics, small claims courts and/or superior court mediation programs. Examples of these types of clinical initiatives include the programs offered at UBC, Windsor, Osgoode, Harvard and Missouri, in which students have outreach opportunities with local small claims courts and/or other organizations. ${ }^{356}$ Further, the Osler Hoskin Harcourt

iso See supra note 127. In addition to Alberta, this competition is conducted at other law schools, including Osgoode.

is! Discussed supra note 194

is: Discussed supra note 179 and surrounding text.

"st Discussed supra noles 192.94 and surrounding text

s4. Suzanne J. Schmitz. "The Role of Law Schools in Improving Access in Justice: The Story of the Southern Illinois University School or Law and the Family Mediation Program" (2003) 28 S III U.t. I I at 1-2.

iss Jid. at 8

13, See "How We Got to Yes," supra note 80 at 12-13; "ADR Survey," supra note 14. For a useful gencral discussion, see Don Peters, "Oiling Rusty Wheels: A Small Claims Mediation Narrative" (1998) 50 Flil L. Rev. 761 . 
Internships in Law Program offered at Windsor provides many of the same benefits. ${ }^{357}$

A potential model sees dispute resolution services being offered to students as well as low income members of a local community by trained LL.B. students, supervised by a trained faculty member or member of the local bar. ${ }^{358}$ The UBC CoRe Program, Windsor's UWMS, Western's Dispute Resolution Centre and Carleton's University Mediation Centre could provide useful Canadian models on which to base this type of initiative. ${ }^{359}$ The Missouri clinical program provides an excellent international model. ${ }^{360}$

\section{d. Graduate Programs}

Faculties of law should be encouraged to develop and expand graduate studies in ADR, including full-time and revenue generating part-time, course-based LL.M. programs, ${ }^{361} \mathrm{Ph} . \mathrm{D}$. programs, as well as other interdisciplinary graduate programs. ${ }^{362}$ And to the extent that a broad cross-section of students can be attracted (international and domestic, academics and practitioners), the more collaborative and expansive the thinking and research productivity will be.

\section{e. Professional Development}

Finally, to the extent that faculties of law have the capacity and resources, expanding into the area of professional development can help further to expand the project of ADR thinking and reform into the legal marketplace. ${ }^{363}$ This will be particularly useful as more research efforts are focused on institutional design and the role of lawyers and judges in the context of court-connected dispute resolution and access to the civil justice system.

\section{Potential ObJections AND Responses}

In this part of the article I identify three specific potential objections to my arguments, to which I also now respond. ${ }^{364}$

Discussed supra note 140.

It may be that, in addition to supervision, the appropriate model would be one of co-mediation (students accompanied by trained mediators). To the extent that students were mediating on their own, it would be critical that adequate supervision and prior training were provided.

334 See discussion of the UBC, Windsor, Western and Carleton clinical programs, supra notes 107, 139, 143, 166 and surrounding text.

wo See discussion of the Missouri clinical program, supra note 210 and surrounding text.

361 In Canada, see Osgoode's full and part-time LL.M. programs, discussed supra note 154 and surrounding text. Internationally, see Missouri's approach to its LL.M. program, discussed supra note 208; Monash's program, supra note 230; Melbourne's program, supra note 234; Queensland's program, supra note 239 and surrounding text.

In Canada, see e.g. the programs at Victoria, supra note 94; UBC, supra note 103, Carleton, supra note 164; Royal Roads, supra note 167 and surrounding text. Internationally, see e.g. the program at Stanford, supra note 189 and surrounding text.

In Canada, see e.g. the programs at Victoria, ibid:; UBC, ibid: Toronto, supra note 145; Dalhousic. supra note 112; Calgary, supra note 129; Osgoode, supra nole 150 and surrounding text. Internationally, see e.g. the programs at Harvard, supra note 172; Bond, supra note 223; Victoria University of Wellington, supra note 250 and surrounding text.

Mot My thinking in this section has been influenced in pan by Russell Engler. See "The MacCrate Report Tums 10," supra note 34 at 114-23. 


\section{ADR IS NO UTOPIA}

As a preliminary matter, I fully acknowledge (and in fact argue ${ }^{365}$ ) that ADR is not for everyone and for every case. ${ }^{366}$ Some cases, and some people, simply do not lend themselves well to ADR processes. ${ }^{367}$ For example, there are many cases involving issues of some interest - direct or indirect - to the public that should not be subject to the closed doors of ADR privacy. And in any event, even if we acknowledge that many cases are fit for ADR, ADR alone is not going to "fix" the problem of access to justice. As the scope of the CBA Task Force Report alone demonstrates, the problem of access touches all institutional aspects of law and the legal profession. Further, as Roderick Macdonald has argued, even institutional reform - including alternative systems of dispute resolution - may not capture all that is needed to make a truly accessible and fair system of justice. According to Macdonald:

Experience has shown that true access to justice means more than overcoming the time, cost and complex barriers that limit people's ability to deploy official institutions to help resolve a legal problem. Making dispute-resolution institutions more objectively accessible will not overcome the main failings of official law simply because oficial law is, in myriad ways, the cause of these failings. Subjective, not objective, barriers bulk largest. Words like disenchantment, disenfranchisement and disempowerment best capture how many citizens view the justice system.

Our systems of civil justice are not designed to contest or disrupt the existing distributions of social power that stand in the way of broader access. Access to justice will never be achieved through reactive adjudicative institutions that are meant 10 find justice in relationships by simply restoring an unjust status quo ame. Elliciency in the service of injustice is not a social good. So the core access to justice challenge is:

How do we give as much emphasis to the "justice" component of the phrase "access to justice" as we do to the "access" component so that citizens will actually want to pursue justice in courts?

[I]t is time to jettison the belief that a lack of access to justice can be remedied principally by systemic reform and by institutional redesign. Law is a precious resource for mediating human relationships. A failure to ask what we expeet of our law is a failure to ask what we expect of ourselves. Every day we consciously disengage from the hard work of building a more just society. This disengagement is the greatest barrier to access to justice.

ws This article forms part of a broader, ongoing research agenda that, while acknowledging the potential and many positive aspects of ADR (as discussed, for example, throughout this article), looks critically at its deficiencies in terms of democratic accountability and rule of law protections. For an early pan of this research agenda, see "Negotiation, Mediation, Globalization Protests and Police," supra note 7.

k. For general concerns, see e.g. "Against Settlement," supra note 293; "The Privatization of Business and Commercial Dispute Resolution," supra note 293: "Reflections on Judicial ADR," supra note 20; "Barriers to Access to Civil Justice for Disadvantaged Groups," supra note 287. See also William G. Horton, "ADR in Canada: Options for the appropriate resolution of business disputes" (2002) $21: 2$ Advocales' Soc. J. 11.

36) As former Chief Justice Brian Dickson acknowledged, even with adequate institutional design, ADR will only "play a useful role in promoting justice" if "the right kinds of cases are being channelled into ADR" ("ADR, The Courts and The Judicial System," supra note 18 at 234 [emphasis in original]). See also ibid. at 235-37. 
True access to justice requires us to seek and to find meaning in our interactions with others by discovering and nurturing just relationships. In the end, we vindicate the goal of a just and accessible law by making it just and accessible in our own lives. ${ }^{368}$

I agree with Macdonald that "true justice," ultimately, will come from a multi-faceted approach that focuses on increasing justice in our own lives and in our relationships in society. And I further agree that ADR alone, or even together with improvements to our traditional systems of justice, will not accomplish that lofty goal. Having said that, I think that we, as jurists, are as well placed as anyone to assist in the project of making better and more accessible justice. ${ }^{369}$ As Alexis de Tocqueville commented more than 150 years ago, we do possess "special information" that we derive from our "studies" and vocation that places us in a position of unparalleled power vis-ä-vis the citizenry and the government. ${ }^{370}$ With this privilege, in my view, comes a responsibility: a responsibility to use our knowledge and "studies" to improve society. As Roberto Unger has rightly argued:

\begin{abstract}
In between the macropolitics of institulional clange and the micropolitics of personal relations stand other large regions of social experience that an inclusive view of politics must acknowledge. Pan of this middle space $\ldots$ is the nature and content of professional practice. For in the relatively deenergized democracies of today much of the controversy over the basic structure of social life, driven out from the arena of governmentcentered politics, passes into the hands of the professions and lives under the disguise of technical expertise. It matters how the professions relate to the citizenry and how the discourse and practice of each profession suppresses or exhibits Iransformative opportunity in social life. ${ }^{371}$
\end{abstract}

To the extent that we as jurists can and want to participate in the project of making justice truly more accessible, ADR provides us with one very powerful tool for that project. So while I agree with the charge that institutional reform is not the single answer, I do think that it is a critical part of the answer. It is for this reason that I think pursuing ADR research and teaching at law school is an important part of pursuing the reform goals of initiatives such as the $C B A$ Task Force Report designed to improve overall societal access to justice.

\title{
2. ARE WE BEING DRIVEN BY THE BAR?
}

Following on from the academic ability and freedom concern addressed above, ${ }^{372}$ ADR is often thought of as a highly practical topic. As such, some might argue that negotiation, mediation, arbitration and other ADR skills, particularly at a time of increased budgetary pressures, are better taught at bar admission courses, professional development courses or through on-the-job mentoring opportunities. After all, as the argument goes, it is the Bar that is the primary driver behind the reforms set out, for example, in the CBA Task Force Report.

Roderick A. Macdonald, “Access to Justice and Law Reform \#2" (2001) 19 Windsor Y.B. Access Just. 317 at 320, 325 .

For a classic comment on the potential public service opportunities in the legal profession, see Louis D. Brandeis, "The Opportunity in the Law" (1905) 39 Am. L. Rev. 555.

See Alexis de Tocqueville, Democracy in America (1848), ed. by Riclard D. Heffner (New York: New America Library, 1956) at 123-27.

Roberto Mangabeira Unger, Democracy Realized: The Progressive Alternative (New York: Verso, 1998) at 254-55.

See supra notes 313-19 and surrounding text. 
In response, as a threshold matter, while the Bar must be credited for the $C B A$ Task Force Report, the various task force working groups and commissioned papers that informed the $C B A$ Task Force Report and its conclusions were undertaken not by the Bar alone but collaboratively within the civil justice community as a whole (including judges, lawyers, court administrators and academics, together with members of government and the public). Subsequently, academics have been instrumental in the follow-up work stemming from various recommendations found in the CBA Task Force Report. ${ }^{373}$ As such, these initiatives have been - and continue to be - of interest to stakeholders beyond the confines of the Bar. ${ }^{374}$

Further, as a pedagogical matter, while it is true that ADR provides opportunities for practical skills development, it is also a field that brings a significant amount of interdisciplinary theory together with those practical skills. ${ }^{375}$ For example, based on responses to research-related questions on the "ADR Survey," ADR instructors tend to spend about equal time in their classes on theory and practice. ${ }^{376}$ As such, ADR in the law school context provides an ideal opportunity for students really to think about the theory behind various dispute resolution initiatives, while at the same time having the chance to apply those theories in practical applications and exercises.

Canada's former Chief Justice Brian Dickson commented at a conference on legal education that, "[i]t seems to me that a truly good education must speak to the practical application of the things learned and that, similarly, good professional training must be firmly grounded in broad historical and conceptual principles." ${ }^{377}$ I agree, particularly in an area such as ADR. Further, to the extent that students seek to have more "practical" issues discussed at law school, ADR certainly can fill that role. As such, while there are numerous voices throughout the civil justice community calling for more ADR training at law schools, there are equally strong voices from the academy singing from the same song book.

\section{COST OF REFORMS}

As with all significant curriculum initiatives, there is a potential concern that the cost of such reforms will not justify the benefits. While I do not purport in this article to address head-on the issue of funding amounts and sources, I do, in this section, address the visceral, but typically misguided, objection that ADR reforms simply "cost too much."

\footnotetext{
3" Sec e.g. Antirudes - Skills - Knowledge, supra note 14 at i.

171 am grateful to Diana $J$. Lowe for raising this argument.

13) See "The Alternative Dispule Resolution Grab Bag," supra note 314 at 754. For a discussion of present and future resenrch in the field of ADR, see supra Part VI.B.2.

1". "ADR Survey," supra note 14.

im Rt. Hon. Brian Dickson, P.C., "Excerpts from the Speech Delivered at the Closing Dinner of the Conference on Legal Education" in Roy J. Matas \& Deborah J. McCawley, eds., Legal Education Canada (Ottawa: Federation of Law Societies of Canada, 1987) at 69, cited in Attitudes - Skills Knowledge, supra note 14 at 14. For a useful background article on the issue of the "purpose of law school," see Bethany Rubin Henderson, "Asking the Lost Question: What Is the Purpose of Law School?" (2003) 53 J. Legal Ed. 48.
} 
First, when one looks closely at the actual reform ideas discussed in this article, ${ }^{378}$ they do not contemplate either the expenditure of significant sums of money or the tying up of massive amounts of capital resources. Quite frankly, the ideas were designed, in part, with cost-effectiveness in mind. To the extent that faculties consider adding a dedicated institute, there certainly will be start-up and ongoing funding requirements. But absent those costs (which in my view are worthwhile), the primary increase in expense connected with these reform ideas will be human costs.

When courses are added to a curriculum, instructors are obviously needed. And given that ADR courses are invariably best taught in small group and seminar formats, the need for more instructors may be significant. ${ }^{379}$ Further, to provide the appropriate balance of theory and practice contemplated by former Chief Justice Dickson, ${ }^{380}$ those instructors will have to be adequately trained and be chosen with those balanced interests in mind. As such, new faculty hires may be required. It may also be the case, however, particularly given the subject matter involved, that non-faculty practitioners can play a meaningful role in covering some of the more practical teaching requirements. Based on the "ADR Survey," most faculties involved in the study already make significant and successful use of non-faculty instructors in numbers of courses and programs. Toronto and Queen's, for example, currently rely almost entirely on non-faculty instructors for their dispute resolution course offerings ${ }^{3{ }^{81}}$ As such, even if a faculty were not inclined to hire new faculty members interested in the area of dispute resolution and the administration of civil justice, the reform ideas contemplated in this article would not necessarily be a fatal financial or other burden on a given faculty's current resources.

I realize that there is a significant downside to this concession (of relying, at least in part, on non-faculty instructors). Without faculty members dedicated to the specific topic of dispute resolution, the field will simply not move forward and continue to develop as a serious academic discipline. After all, it is through dedicated researchers and instructors that innovative work gets done in any given field. The traditional use of non-faculty instructors in this area of the curriculum is likely a causal reason for why ADR has been comparatively slow to develop as a serious academic discipline and why so many leading academic institutions - particularly in the United States - have done relatively little in the field. As such, we certainly need to be cautious about relying exclusively on non-faculty instructors to teach and research in the area. ${ }^{382}$ However, assuming that a balance can be struck through the use of faculty and non-faculty members - particularly by strategically using practitioners in practice-heavy courses - the costs of these reform proposals should not be prohibitive.

Second, and in any event, the benefits derived from the adoption of these recommendations and approaches - in terms of: (a) addressing current student demands; (b) attracting future LL.B. and graduate students; (c) addressing head-on worldwide access to justice and law reform policy concerns; and (d) establishing leading dispute resolution programs that are consistent with the modern realities and requirements of the legal academy

\footnotetext{
372 Sec supra Pant VI.B.

379 I am grateful to Frank Sander for comments on this issue.

38) See supra note 377 and surrounding text.

361 See supra notes 145 and 157 and surrounding text.

3n2 I am grateful to Frank Sander for comments on this issue.
} 
and profession - far outweigh any costs incurred in the development of these initiatives. These benefits will accrue to the benefit of a given institution, in terms of tuition, ${ }^{383}$ research funding, international academic recognition and alumni support. They will also accrue to the benefit of the profession and society in terms of addressing the access to justice issues raised by the numerous reform proposals discussed in this article. As such, I see this cost objection, while real, as one that can and should be overcome.

\section{Conclusion}

Justice, including its accessibility and reform, is the primary focus of the worldwide reform initiatives discussed earlier in this article. One of the primary tools identified by those initiatives, which can assist in the project of making civil justice more accessible, is ADR. Keeping in mind the important caveat that ADR is only one tool among others, and an imperfect one at that, ${ }^{384} \mathrm{I}$ agree with those reform initiatives and their view of ADR as a useful tool in making civil justice more accessible.

At the outset of this paper, I included the statement by Adams and Bussin that "ADR is an approach to justice whose time has come. ${ }^{\text {"385 }}$ Significant in this statement, in my mind, is its implied recognition that ADR is a procedural tool that can be imagined and re-imagined, not just in the service of private clients, but also in the service of justice generally. I think we as academics have a duty to assist with the project of reform by assisting with the imagining and re-imagining of ADR's full potential. As I have acknowledged, we have already seen significant developments in ADR research and teaching. As I have also argued, there is still much to be done. The reform ideas and recommendations discussed in this article are presented with this future work in mind. In the spirit of improved access to justice for all, it's time to get busy.

Osgoode's part-time LL.M. program in ADR, for example, costs "approximately $\$ 16,000$ " (for 2003 admission). There are approximately 35-50 North American ADR students enrolied each year: "ADR Survey," supra note 14. See also online: Osgoode Hall <www.law. yorku.ca/pdp/llm/lmmain.htm>. 